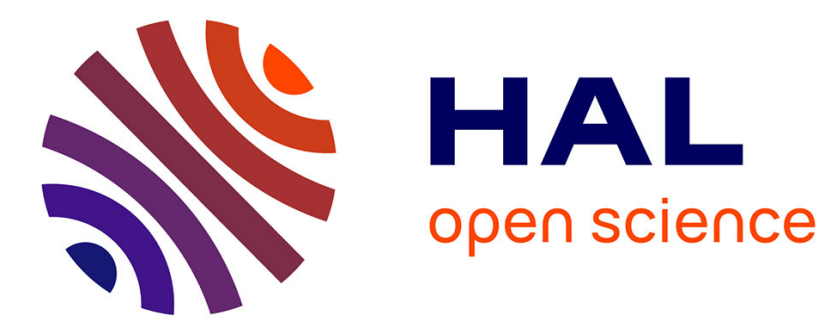

\title{
Interest rates, inflation, and exchange rates in fragile EMEs: A fresh look at the long-run interrelationships
}

Hüseyin Şen, Ayşe Kaya, Savaş Kaptan, Metehan Cömert

\section{To cite this version:}

Hüseyin Şen, Ayşe Kaya, Savaş Kaptan, Metehan Cömert. Interest rates, inflation, and exchange rates in fragile EMEs: A fresh look at the long-run interrelationships. 2019. halshs-02095652v2

\section{HAL Id: halshs-02095652 \\ https://shs.hal.science/halshs-02095652v2}

Preprint submitted on 25 May 2019

HAL is a multi-disciplinary open access archive for the deposit and dissemination of scientific research documents, whether they are published or not. The documents may come from teaching and research institutions in France or abroad, or from public or private research centers.
L'archive ouverte pluridisciplinaire HAL, est destinée au dépôt et à la diffusion de documents scientifiques de niveau recherche, publiés ou non, émanant des établissements d'enseignement et de recherche français ou étrangers, des laboratoires publics ou privés.

$$
\text { Copyright }
$$




\title{
Interest rates, inflation, and exchange rates in fragile EMEs: A fresh look at the long-run interrelationships
}

\author{
by Hüseyin Şen ${ }^{a}$, Ayşe Kaya ${ }^{b}$, Savaş Kaptana ${ }^{a}, M^{2}$ etehan Cömert ${ }^{a}$
}

This Version: 24 May 2019

\begin{abstract}
This study attempts to establish the possible existence of the long-run interrelationship between interest rates, inflation, and exchange rates in five fragile emerging market economies (Brazil, India, Indonesia, South Africa, and Turkey), what is so-called by Morgan Stanley 'Fragile Five'. To do so, we utilize Li and Lee's (2010) Autoregressive Distributed Lag (ADL) test for threshold cointegration and apply it to sample countries' monthly time-series data from 2013:1 to 2018:12. Overall, our primary results are threefold: First, there seems to be a long-run positive relationship between actual rates of inflation rates and nominal interest rates supporting the validity of the ex-post Fisher hypothesis for all the sample countries. Second, the sample countries' data supports the presence of a cointegrating relationship between interest rates and exchange rates for the case of Brazil, India, and Turkey but not for the case of Indonesia and South Africa. Lastly, without exception, exchange rates and actual rates of inflation in all the sample countries examined tend to co-move in the long-run, implying that the depreciation of their currencies creates inflation through raising the prices of imported goods. The results above are widely compatible with both theoretical expectations and the results of the most previous empirical studies on the long-run interrelationships between interest rates, inflation, and exchange rates in the literature.
\end{abstract}

Keywords: Macroeconomic policy, macroeconomic policy management, emerging market economies, autoregressive distributed lag, threshold cointegration.

JEL codes: E31, E43, E52, E58, E60

\section{Acknowledgements:}

The authors are grateful to İhsan Kulall, Cem Çebi, Abdullah Tirgil, Zeynep B. Çevik, and Barlş Alpaslan for their valuable comments and suggestions.

\footnotetext{
a Ankara Yıldırım Beyazıt University, Department of Public Finance, Ankara/Turkey.

b İzmir Kâtip Çelebi University, Department of Public Finance, İzmir/Turkey.
} 


\section{Introduction}

Interest rates, inflation, and exchange rates are three fundamental macroeconomic variables for a country's economy. Taken together, they take place at the heart of the economy as the macroeconomic barometers, giving signals regarding the macroeconomic performance of the economy. Even in practical terms, as the prominent macroeconomic policy variables, they play a central role in not only determining but also influencing both real and nominal economy. Therefore, the possible presence of the long-run interrelationships between them always receives considerable attention from a broad range of society's interest, ranging from policymakers and academic macroeconomists to investors, companies, and even households.

In today's globalized world, this attraction has become layered. Perhaps, the plausible grounds behind this have been the changes in a macroeconomic policy environment pursued by countries with global integration resulted from globalization. So, understanding the interrelationships between the above-mentioned variables is matter and constitutes a basis for designing an appropriate and stable macroeconomic policy. From this point of view, many countries have put into practice a bunch of macroeconomic policies, i.e., fiscal, monetary, and exchange rate policy, which is compatible with their economic targets in recent decades.

In conducting the present study, several factors motivate us. First and foremost, interest rates, inflation, and exchange rates are dynamic macroeconomic variables for every lively economy. Second, the sample countries have a critical role in today's global economy. For instance, as of 2017, these countries alone account for 8.5 percent of the world GDP. ${ }^{1}$ Many look at them together with other emerging market economies as the engine of global growth. Despite this fact, to our knowledge, there is no previous study examining the interrelationships between three variables together in the context of five fragile economies. Third, in the sample countries, the reaction of interest rates, inflation, and exchange rates to domestic as well as international economic and political developments appears to be stronger in relation to other emerging market economies. This makes these countries more vulnerable to sudden and/or unexpected changes in the domestic as well as international economic and political climates. It is partly due to these countries' economic and political structure and partly due to the degree of their integration with the global economy. Finally, the sample countries, without exception, have recently introduced new strategies in setting their macroeconomic policies compatible with floating exchange rate regimes, such as inflation targeting. ${ }^{2}$ Exchange rate volatility either alone or together with interest rates variability makes the topic more important for all the analyzed countries. In this context, the 2008-09 global crisis compelled countries to reassess how there is coherence between macroeconomic policy tools in providing macroeconomic stabilization, including financial stability. In this assessment, in particular, the role of the exchange rate regime adopted came into prominence.

This study revisits the highly disputed topic in both theoretical and empirical grounds. In this context, it empirically examines the long-run interrelationships between interest rates, inflation, and exchange rates by using the data from five fragile EMEs. In short, the study seeks to answer the following questions: Is there long-run interrelationships between the three variables in the sample countries? If so, what kinds of empirical relationships exist between them and how to justify these interrelationships?

\footnotetext{
${ }^{1}$ The figure is based on the World Bank's national accounts data, and OECD's national accounts data files in 2017.

${ }^{2}$ The year of adopting inflation targeting is 1999 for Brazil, 2016 for India, 2005 for Indonesia, 2006 for Turkey, and 2000 for South Africa, respectively.
} 
Against this background, the study aims to test the possible existence of the long-run relationships between interest rates, inflation, and exchange rates in the countries under scrutiny by using quarterly time-series data from January 2013 to December 2018.

In this study, we employ Li and Lee's (2010) Autoregressive Distributed Lag (ADL) test for threshold cointegration as the method of estimation. This estimation method has several superiorities compared to its rivals. First, the ADL test does not require the classification of variables into $I(1)$ or $I(0)$. Other cointegration procedures, such as those proposed by Engle and Granger (1987) and Johansen (1988), require checking the order of the integration of variables by using unit root tests and all variables in the model must be integrated of the same order. Second, the ADL test provides better performance in small sample sizes. Lastly, it allows for estimating the long- and the short-run parameters of the model simultaneously. Since the ADL test can overcome these three critical problems, our empirical results contribute to the understanding of the research questions that we seek to find answer in this study.

The remainder of the study is organized as follows: The following two sections provide a comprehensive background to the study, focusing on not only the theoretical aspects of the possible relationships between interest rates, inflation, and exchange rates but also their empirical aspects respectively. The proceeding section lays out the econometric analysis of the study. As for Section 4, it first reports the estimation results, and then justifies them. Section 5, the final section, summarizes and concludes.

\section{Theoretical considerations}

\subsection{Interest rates-inflation-exchange rates nexus in theory}

The relationship between interest rates and inflation is one of the most interested as well as the long-debated topics in macroeconomics literature. As is known, central banks, as monetary authorities, have the power of altering interest rates by manipulating the money supply. Then, variations in interest rates are likely to influence both exchange rates and inflation through the monetary transmission mechanism. For instance, in an open economy, under the assumption of perfect capital mobility, an increase in domestic interest rates provides an opportunity for lenders to obtain a higher return from the domestic and foreign interest rates differentials. Thus, it creates an attractive environment for foreign capital in- and out-flows. The influx of foreign capital, all else being equal, leads to an appreciation of the national currency, putting pressure over the exchange rate to rise, or vice versa. Of course, it is probable that the volatility effects of interest rates on exchange rates may be mitigated to some extent if there exists a difference in the rates of inflation between the home country and the rest of the world. Theoretically, at least, it is also expected that interest rates influence inflation.

The standard view that relates interest rates with inflation is often attributed to the Irving Fisher and his seminal work of 1930. In the mentioned study, Fisher establishes a direct longrun link between nominal interest rates and the expected rates of inflation and thus postulates that nominal interest rate $[i]$ is equal to the sum of real interest rate $[r]$ plus the expected rate of inflation [ $\pi$ ]. Algebraically speaking, it can be expressed as $i=r+\pi^{e}$ for the same term in the long run. In this link, however, there is no connection between changes in the expected rates of inflation and changes in real interest rates. In economic terms, real interest rates are not affected by the expected rates of inflation. 
Then, it is safe to argue that the Fisher hypothesis, or the Fisher equation, is a good starting point to analyze the interest rate-inflation relationship. The Fisher equation hints at that permanent changes in the expected rate of inflation-that are equal to actual inflation rates under the assumption of adaptive expectations-exert no long-run effect on the real interest rates. This is to say that, as long as the hypothesis holds, real interest rates are stable. From the Fisher hypothesis standpoint, the real interest rates are determined by some other macroeconomic fundamentals, such as productivity of the capital and time preference of investors in the economy rather than monetary shocks (Nusair, 2009).

With regard to the real interest rates and expected rate of inflation, Hakkio (1986) draws attention the fact that both variables are influenced by a variety of factors. According to the author, the most important element that influences the real interest rate is the demand for and supply of available funds in an economy. When it comes to the expected rate of inflation, changes in it are closely related to various temporary and permanent factors, such as one-time changes in the price of food and/or energy, government policies, military and political issues, etc.

The existing literature holds several transmission mechanisms through which interest rates can influence exchange rates. In the related literature, interest rates are widely related to inflation and exchange rates alike. Accordingly, for instance, a reduction in the interest rates allows consumers to borrow more money with a relatively lower cost. From the consumers' viewpoint, this means that, other things being constant, they will have an opportunity to spend more money, and thus stimulating aggregate demand and resulting in inflationary pressure. By contrast, if the interest rates rise and then it is expected that consumers will have to borrow less money. Consequently, they will have less opportunity to spend, resulting in a decline in inflation. In short, the Fisher equation states that there exists a positive one-to-one nexus between the expected rate of inflation and nominal interest rate with the Granger-causality running from the former to the latter.

\subsubsection{Interest rates-inflation nexus}

The possible linkages between interest rates and inflation are a long matter of concern among researchers. The origin of the debate over the interest rates-inflation nexus is usually attributed to the studies of the Swedish economist Knut Wicksell. Wicksell (1907, 1936[1898]) originally introduced the concept of neutral [natural] interest rate, also known as the Wicksellian rate of interest, which refers to the equilibrium value of the real interest rate at the natural level of output. This interest rate is regarded as an interest rate in the goods market in which demand and supply of goods are in equilibrium. In the eye of Wicksell, the natural interest rate provides not only a monetary equilibrium, but also a real equilibrium for the economy. Herein, the monetary equilibrium implies the presence of a stable price level, while real equilibrium denotes consistency between saving decisions by households and investment decisions by firms. Any deviation of the market rate-that is, the money rate of interest appearing at the capital market-from the neutral interest rate results in changes in the prices through the Wicksell's cumulative process which explains how the difference between natural interest rate and market rate results in increases in prices (see Wicksell, 1936[1898]). Accordingly, suppose that if the market interest rate is lower than the natural one, in such case, the level of economic activity will enhance and thus a rise in prices will occur. And then, increases in prices will put further pressure on the real interest rate, resulting in a further rise in the level of economic activity and therefore at prices. 
A couple of decades later from Wicksell, Fisher (1961[1930]) in his seminal work claimed that the expected rate of inflation affects nominal interest rates. To Fisher, for example, a decrease in the prices will make companies borrow less since their profit levels will fall. Then, less borrowing will results in a decrease in interest rates. For households, the situation would be almost the same in such a way that disinflation makes for them to deposit their money in a bank at a lower interest rate as they care about the real return on their savings.

Sargent (1973) criticized the Fisher equation, expostulating that the Fisher equation is inadequate in explaining the relationship between inflation and interest rates. Contrary to Fisher's proposition, the author argued that there is a bidirectional Granger-causality between the expected rates of inflation and interest rates wherein the causality runs from the former to the latter. The author further argued that the critical thing in explaining the link between the two variables is how price expectations are formed. Accordingly, actual inflation influences expected inflation and then through which it puts pressure on nominal interest rates.

One should keep in mind that increases in prices may not just affect interest rates but also are likely to be affected by them as well. The standard IS-LM model can help us to shed light to this relationship. Considering the standard IS-LM framework, for example, other thing being equal, an increase in the money supply shifts the LM curve to the right and result in an increase aggregate demand and, by implication, output. So, it is expected that firms will respond to increasing prices by rising demand for supply. However, this respond will not be quick since the supply curve is inelastic in the short run.

Moreover, interest rates provide information regarding future projections of macroeconomic variables, such as inflation. To illustrate the point: Economic agents and/or market participants consider expected rates of inflation when they manage their savings and budgets. In doing so, they propose to maximize the real rate of return on their savings. So, it can be argued that higher nominal interest rates might be positively associated with higher inflation expectations. Fama (1975) concludes that n-month predictions about inflation can be made with the help of n-month bills. Also, Engsted (1995) establishes a link between interest rates and inflation. However, unlike Fama (1975) that took into account the short-term interest rates, Engsted (1995) used the longterm interest rates as a predictor of inflation.

\subsubsection{Interest rates-exchange rates nexus}

In reviewing the related literature, one sees that the theoretical relationship between interest rates and exchange rates is typically explained in the context of exchange rate determination. Accordingly, the differential between domestic and foreign interest rates is one of the fundamental determinants of exchange rates. For instance, the IMF traditionally claims that the interest rate differentials among countries dictate the movement of foreign capital in- and out-flows from one country to another.

The existing literature also provides some counter-arguments to the above standard explanation. In this regard, Frankel (1979) provides two basic approaches in explaining the linkages between interest rates and exchange rates: One is international goods market approach, and the other is asset market approach. Accordingly, interest rates can be linked with exchange rates through the latter one. Because both interest rates and exchange rates may exert an effect on global asset prices while international goods market is not directly related to interest rates. Concerning the asset market approach, Frankel (1979) acknowledged that there exist two alternative views as the Chicago and Keynesian views. The Chicago view argues that under perfectly flexible prices, changes in market interest rates are primarily determined by the expected rate of inflation. 
If domestic interest rates tend to increase in relation to the rest of the world, then it is thought that market participants have already priced the increases in the expected rate of inflation. In this case, it is expected that domestic currency will lose value owing to depreciation effect of inflation. Therefore, the exchange rate in terms of domestic currency increases (depreciation) since the demand for domestic currency decreases. Consequently, this purports that exchange rates move in the same direction with nominal interest rates. The Keynesian theory, in contrast, suggests that under the validity of sticky prices, higher market interest rates resulted from tightening monetary policy actions create an attractive environment for capital inflows into the host country. This is because higher interest rates in the absence of increases in inflation rate drive up real interest rate that is a real return on domestic currency for foreigners. As a consequence, there would be an appreciation of the domestic currency by reason of increasing demand. In brief, exchange rates move inversely with interest rates under the assumption of sticky prices. Also, developing global financial system contributes to the emerging of such a mechanism through carry-trade operations that enable investors to borrow in terms of the currency having lower interest rate and lend in terms of a currency pays higher interest.

In a theoretical contribution aiming to develop a theory of exchange rate movements under perfect capital mobility, Dornbusch (1976) asserted that interest rates are negatively associated with exchange rates in the short run. According to Dornbusch (1976), if economic agents and/or market participants expect depreciation in the domestic currency, then the market will price this instantly by increasing interest rate. This pretends to interest rate parity condition which argues expected depreciation of a currency against others is equal to the difference between the interest rates of two countries.

\subsubsection{Exchange rates-inflation nexus}

A good starting point for analyzing the relationship between exchange rates and inflation is to take a close look at Barro and Gordon (1983). In their pioneering study, the authors proposed a theoretical argument on the exchange rate-inflation nexus in the context of monetary policy credibility. Barro and Gordon's (1983) paper argued that a fixed or stable exchange rate policy could make easier the task of the monetary authority in lowering inflation by increasing credibility. This argument was also put into words in the following years by some scholars, including Giavazzi and Giovannini (1989), Velasco (1996), and Dornbusch (2001). They all contended that a stable exchange rate regime provides not only price stability but also increase the efficiency of monetary policy. Under such a regime, an economy with a relatively higher inflation rate against the rest of the world is likely to encounter persistent external deficits and therefore a reduction in its FX reserves. This may pose a serious risk for both the sustainability of persistent deficits and FX reserves. To avoid such problems, the authorities will try to restrain its excessive inflation rate. Under the flexible exchange rate regime, as opposed to a fixed one, this would not be the case since external disequilibria are automatically and instantaneously corrected by variability in the exchange rates.

Another argument in favor of a fixed exchange rate regime is that it will increase the credibility of monetary policy. Increasing the credibility of monetary policy will allow the monetary authority to conduct its commitment to low inflation. All these will act as an anchor for inflationary expectations. Reducing inflationary expectations will help not only lowering the velocity of money but also lowering the sensitivity of prices to temporary monetary shocks (Levy-Yeyati and Sturzenegger, 2001). Besides, the fixed exchange rate regime may contribute to having lower rates of inflation by creating a confidence effect-that is, a greater willingness to hold domestic currency rather than goods or foreign currencies (Ghosh et al., 1997). By contrast with, the floating exchange rate regime, unlike the fixed one, is associated with overshooting of the 
equilibrium exchange rate in both directions and cause prices to go up by increasing the domestic prices of imported goods when depreciation occurs, but fail to reduce prices while appreciating-the so-called ratchet effect. On that account, it can be claimed that inflation is likely to be higher under a floating exchange rate regime in relation to a fixed one.

Against the unfavorable arguments above, of course, there are some counter-arguments in favor of the flexible exchange rate regime for having lower rates of inflation. For instance, Tornell and Velasco (1995) argued that flexible exchange rate regimes allow the effect of unsound fiscal policies to be reflected in exchange rate movements and given that inflation is costly for fiscal authorities, the flexible rates enforce transparency and provide more policy discipline by forcing them to pay the cost. It is also argued that flexible exchange rate regimes provide monetary independence, which, in turn, is crucial for tracking the monetary policy in a growth-friendly manner while reducing unemployment. In terms of its impact on growth, monetary policy independence with a fully flexible exchange rate regime will ensure the government to focus on the optimal rate of inflation that produces a positive environment for economic growth (Hernandez-Verme, 2004).

In an open economy with a fully flexible exchange rate system, it is very probable that an appreciation or depreciation in exchange rates influence the price of imported goods, provocating consumer and producer price indexes to drive up. This is primarily a case for import-dependent economies which are vulnerable to external shocks as in the case of the countries in the present study. The link between exchange rate and inflation comes out through the passthrough effect of exchange rate volatility, inducing changes in domestic prices. Needless to say, to what extent the exchange rate pass-through effect would occur depends mainly on the price elasticity of demand and supply for imported goods. If the price elasticity of goods is low, for instance, then the pass-through effect will be relatively small since economic agents would prefer other substitutable goods that are relatively cheap. It is also important to stress here that, as emphasized by Devereux and Yetman (2002), sticky prices may cause to be delayed the pass-through effect on the county economies for a while. This could be the case especially when prices do not flexibly adjust to changing dynamics. In such cases, changes in the exchange rates may not influence domestic inflation for considerable time periods or vice versa, varying in line with the circumstances. On the other hand, it is also likely that inflation affects the exchange rates. Inflationary expectations may lead to exchange rate volatility. Especially this may be a case when economic agents and/or market participants have inflationary expectations that will result in a depreciation of the domestic currency. If there exists such a case, then they will tend to sell off the domestic currency as buying the foreign currency. This process will end up with weakening the domestic currency against the foreign currencies.

Another possible channel that could be considered is the exchange rate pass-through. It may create an inflationary effect by increasing the prices of imported goods. What we point out is that the effects of exchange rates on domestic inflation emerge by means of exchange rate pass-through. A country's foreign trade is a critical factor that is likely to affect domestic prices and thereby inflation by depending mainly on the magnitude of a country's foreign trade structure and volume. The overall level of prices is influenced by the prices of all items that take place in the consumption basket of that country. If the country relies heavily on imports of goods for either domestic consumption or investment or any other purposes, in such a case, domestic prices in this country would be very sensitive to price changes in the exportingcountries. As such, an appreciation of foreign currency, for example, will create a pass-through effect from exchange rates to inflation and thus put pressure over domestic inflation to rise or vice versa. On the other hand, this pass-through effect of volatility in exchange rates also poses a risk on export-oriented countries that relies mainly on import to make export through a process 
characterized simple as follow: An increase in the exchange rates leads to a parallel increase in import prices, and then an increase in import prices affects the prices of domestic tradable goods. On balance, what emerges from the above theoretical arguments is that there are divergent views regarding exchange rates-inflation link in the existing literature.

\subsection{Empirical background to the study}

\subsubsection{Empirical literature on the interest rates-inflation nexus}

An old, but still oft-cited, paper by Fama (1975) studied the possible presence of a relationship between short-term interest rates and inflation considering the case of the US. The author's results indicated that there is a strong positive relationship between interest rates and inflation rates, running from inflation rates to short-term interest rates. According to the Fama (1975), this is the case, especially in the bill market. However, the author holds the view that in determining current inflation rates, not only interest rates but also past inflation rates play a critical role. Like Fama (1975), Mishkin (1992) also considered the case of the US and explored the level of interest rates-inflation relationship referring to a strong Fisher effect by using the post-war U.S. data. However, contrary to Fama (1975), Mishkin (1992) found no evidence in favor of a short-run Fisher effect whereas enough evidence supporting the existence of a longrun Fisher effect. Based on the findings, the author argued that his findings are consistent with Fisher's original proponent on the inflation-interest rate relationship. However, he drew attention to the fact that Fisher did not propose that there should be a robust short-run relationship between expected rates of inflation and interest rates. On the contrary, he asserted that there is a positive relationship between interest rates and inflation, but this is a long-run phenomenon rather than a short-run.

Drawing on the data from four developed countries (the US, Belgium, Canada, and the UK), MacDonald and Murphy (1989) tested the long-run bivariate relationship between interest rates and inflation. The authors found evidence supporting the Fisher relationship. However, the validity of the relationship was less strong than expected. Instead, the authors' findings confirmed a weak relationship between inflation and interest rates for the case of the US and the UK and a semi-strong relationship for the other two countries in the long run. The authors justify these findings on the ground of the exchange rate regime adopted by these countries. On this point, they argued that when the exchange rate regimes of the sample countries are considered and then they are broken down into two sub-components as the fixed and floating regimes, it appeared that there is some evidence of a cointegrating relationship for the US and Canada for the fixed exchange rate periods, while there is no evidence of the cointegration for either a weak or semi-strong form in any of the sample countries.

In a follow-up paper, Koustas and Serletis (1999) looked at the possible existence of the Fisherian link between inflation and short-term nominal interest rates in 11 developed countries ${ }^{3}$. The paper's findings suggested that the Fisher effect is robust only for Canada, the UK, and the US as it is weak for France, Germany, and the Netherlands. However, for the remaining countries, the long-run Fisher effect was strongly rejected. Overall, the authors argued that the sample countries' data overwhelmingly rejects the Fisher effect, showing similarity with what Mishkin (1992) found. Using the panel smooth transition regression model, a fresh paper by Kim et al. (2018) came to the almost same conclusion with Mishkin (1992), providing no clear-cut evidence with regard to the co-movement of inflation and interest rates. The authors, however, suggest that

\footnotetext{
${ }^{3}$ These countries are: Belgium, Canada, Denmark, France, Germany, Greece, Ireland, Japan, the Netherlands, the UK, and the US.
} 
the effects of inflation on interest rates vary with the size of the inflation rate. A paper based on cointegration analysis by Payne and Ewing (1997) also yielded mixed evidence in the context of a set of lesser-developed countries. Their results support the validity of the Fisher relationship only for four out of nine sample countries (Malaysia, Pakistan, Singapore, and Sri Lanka). There is no long-run relationship between interest rates and inflation rates in the remaining five countries: Argentina, Fiji, India, Niger, and Thailand. The authors contended that for each of these five countries, the real interest rate is non-stationary in levels. Similarly, Carneiro et al. (2002) revealed no homogenous results for three big Latin American countries: Mexico, Argentina, and Brazil. The authors' analysis revealed that there appears to be a stable long-run relationship between nominal interest rates and inflation rates just for Argentina and Brazil.

For a group of 26 developed and developing countries, on the contrary to what the authors found above, Berument and Jelassi (2002) documented that there is strong evidence in favor of the Fisher equation in more than half of the countries under scrutiny in the long run. Additionally, the authors drew attention to the fact that the Fisher hypothesis holds more for the developed countries rather than the developing ones.

Tsong and Hachicha (2014) tested the validity of the Fisher hypothesis for a group of four developing countries, consisting of Indonesia, Malaysia, Russia, and South Africa. The author's results suggested that there is a long-run relationship between interest rate and inflation. However, they noted that the shocks affect the long-run coefficients between nominal interest rates and inflation, hinting at the existence of an unstable relationship between the two. More specifically, in the upper quantiles there is a one-to-one relationship between nominal interest rates and inflation, confirming the validity of the Fisher effect, while in the lower quantiles, the nominal interest rate responds by a lower percentage than the change in inflation, referring to the Fisher effect puzzle. The authors attribute their findings to the existence of the asymmetric monetary policy. A subsequent paper by Güriş and Yaşgül (2015) provided mixed evidence, showing that the Fisher equation is valid for Canada, Germany, Italy, and Japan but not for France, the UK, and the US.

Overall, in reviewing the existing literature, what we observe that empirical literature on the Fisher equation has been yielded mixed results up to know, although there is a sizeable body of literature examining the topic. Aside from above-reviewed studies, some other studies, such as Mishkin (1992), Crowder and Hoffman (1996), Berument and Jelassi (2002), Mignon and Lardic (2003), Westerlund (2007), Lai (2008), inter alia, reported robust evidence in favor of the hypothesis. Some others, however, including Coppock and Poitras (2000), Lanne (2001), Udayaseelan and Jayasinghe (2010), Caporale and Gil-Alana (2017), found no evidence for the hypothesis. Also, there is a third party studies which produced either weak and/or mixed evidence. Notable exceptions of such studies are Barsky (1987), MacDonald and Murphy (1989), Payne and Ewing (1997), Ghazali and Ramlee (2003), Sun and Phillips (2004), Ahmad (2010), Köse et al. (2012). ${ }^{4}$

As well, in this context, it is worth noting that the literature contains some other studies that look the topic from the different vantage points: Developed versus emerging market and developing, inflationist vs. non-inflationist, short- vs. long run, and the like. However, it is worth noting here that such studies yielded inconclusive results. This may be attributed to a several factors: Model and sample specification, expectations, monetary regime shifts, the countryspecific elements, and so forth. In a word, the link between interest rates and inflation still remains a puzzle for empirical researchers. So, further studies are needed to clarify the topic.

\footnotetext{
${ }^{4}$ For a comprehensive survey on the Fisher hypothesis, see, e.g., Cooray (2002).
} 


\subsubsection{Empirical literature on the interest rates-exchange rates nexus}

Chen (2006) examined the existence of the possible relationship between interest rates and exchange rates for six developing countries ${ }^{5}$ over the period 1997-2002. The author found that increases in nominal interest rates result in a higher probability of switching to a crisis regime. The author suggests that a high-interest rate policy is unable to defend the exchange rate.

Turning to the empirical works on the nexus between interest rates and exchange rates, we begin by Furman and Stiglitz (1998). The authors concluded that there are two important channels through which exchange rates are likely to be affected by the increase in interest rates. One is the risk of default and the other is the risk premium. Since the uncovered interest parity theory assumes no role for both these channels, the interest rate represents the promised return on domestic assets, i.e., actual interest receipts are equal to promised interest receipts.

Sargent and Wallace (1981) argued that high-interest rate policy might give rise to reductions in demand for money and increases in inflation since increases in interest rates imply increases in the level of government debt which, in turn, would be financed by printing money. As a result, there will be exchange rate depreciation. Similarly, it is highly likely that an increase in interest rate adversely affects the future export performance of a country which would reduce the future flow of foreign exchange reserves and thereby, leads to depreciation of its currency (Furman and Stiglitz, 1998). Another study by Goldfajn and Baig (2002) explored the linkage between real interest rates and real exchange rates for the five Asian countries during the 1997-1998 period by using a VAR model based on the impulse response function from the daily interest rates and exchange rates. They observed the existence of a weak correlation between interest rates and exchange rates.

On the other hand, two separate studies by Patnaik and Pauly (2001) and by Dash (2004), working on a single country, India, found inconclusive evidence on the relationship between interest rates and exchange rates. The former study documented that a high-interest rate differential causes an increase in capital flows and results in an appreciation of the Indian rupee from January 1993 to December 1998. On the other hand, Dash (2004) found the bidirectional Granger-causality relationship between interest rates and exchange rates which runs from the former to the latter and thus an increase in interest rates results in an appreciation of the Indian rupee.

\subsubsection{Empirical literature on the exchange rates-inflation nexus}

The current literature contains numerous studies on the link between exchange rate and inflation. Choudhri and Hakura (2006) for 71 developing and industrial countries, Ca'Zorzi et al. (2007) for 12 emerging markets, Kataranova (2010) for Russia, Leigh and Rossi (2002), Kara and Ögüüç (2008) and Arslaner et al. (2014) for Turkey, Caselli and Roitman (2016) for 28 emerging markets are just some case studies that we observed at first glance in the context of developing and emerging market economies.

Choudhri and Hakura (2006) studied with a large dataset for 71 countries, 52 of which are developing countries, covering the period 1979-2000. The authors examined the pass-through effect and found that it runs from exchange rates to domestic prices. Specifically, they drew attention to the fact that the pass-through effect is subject to the inflation regime (i.e. high inflation versus low inflation regime). So, it is more significant in countries with higher inflation, purporting that the higher inflation, the higher the pass-through effect.

\footnotetext{
${ }^{5}$ Indonesia, South Korea, the Philippines, Thailand, Mexico, and Turkey.
} 
Employing the VAR technique, Kara and Ögünç (2008) analyzed the exchange rate pass-through effects on inflation before and after the adoption of the inflation targeting in Turkey in 2001. The paper's finding revealed that, in contrast to the pre-inflation targeting period, the passthrough from imported inflation to domestic inflation weakens and slows in the post-inflation targeting period in Turkey. The authors justify this on the ground of the followings: i) the decline in the indexation of prices to exchange rates; ii) the enhanced role of inflation targets in pricesetting behavior. Based on their findings, the authors argue that successfully implementing the inflation targeting regime may cause a reduced exchange rate pass-through if the main anchor switches from exchange rates to inflation targets.

Another but a similar study on Turkey by Arslaner et al. (2014) revealed that as with many developing countries, the exchange rate pass-through works and affects domestic inflation in Turkey. Additionally, their study revealed two more important things: i) the pass-through is higher for producer price index in relation to consumer price index; ii) the past currency crisis and the openness to international trade are two important factors for the pass-through in the Turkish case.

Using a sample of 12 EMEs in Asia (China, South Korea, Singapore, Taiwan, and Hong Kong), Latin America (Argentina, Chile, and Mexico), and Central and Eastern Europe (Czech Republic, Hungary, Poland, and Turkey), Ca'Zorzi et al. (2007) investigated the degree of exchange rate pass-through to prices. They found that for those EMEs with only one-digit inflation, passthrough to imports and consumer prices appears to be low. Accordingly, excluding two high inflation countries, Argentina and Turkey, from the analysis, for the others there is strong evidence for the degree of the exchange rate pass-through and inflation, supporting the Taylor's hypothesis (that is, the responsiveness of prices to exchange rate volatility depends positively on inflation). In a nutshell, Ca'Zorzi et al. (2007) provided partial evidence for exchange rate passthrough to domestic prices in the case of EMEs, rejecting the hypothesis that exchange rate passthrough is always higher in the EMEs vis-à-vis their developed country counterpart.

There is also considerable empirical literature that focuses on the causal relationship between interest rates and exchange rates. About exchange rates-inflation nexus, the current literature mostly associates exchange rates with inflation. ${ }^{6}$ Accordingly, there is a co-movement between the two variables wherein the causality runs from exchange rates to inflation. In this relation, the determinant of inflation is considered to be exchange rates. Especially in those countries which depend very much on raw materials and energy-related imports, an increase in exchange rates affects the domestic prices of imported goods and hence brings about an increase in general domestic price level. This process is named in the literature as exchange rate pass-through, indicating the channel through which exchange rates affect domestic inflation.

\section{Empirical analysis}

\subsection{Data and variables}

In this study, we work with monthly time series data for five emerging market economies. The economies included in the sample are Brazil, India, Indonesia, Turkey, and South Africa. Data availability and its frequency are the prime factors for the selecting observation period. Subject to data availability at the highest frequency, the sample period extends from January 2013 to

\footnotetext{
${ }^{6}$ Of course, there are also, some, but relatively fewer, counter-arguments claiming that inflation causes movements in exchange rates. In this regard, see, e.g., Clarida and Waldman (2008).
} 
December 2018 with a total of 72 observations. $^{7}$ The data on CPI inflation and exchange rate variables were retrieved from the Bank for International Settlement's official web site (www.bis.org) whereas the data on interest rates were from the international investment web site (www. investing.com).

As for the variables which we used in our estimation model, they are made up of the following three variables: i) interest rate, ii) inflation, iii) exchange rate.

Our first variable is interest rate which we symbolize it throughout this study as " $i$ ". The widespread practice treats T-bond rates, money market rates, or the lending rates as the major proxies for interest rates. However, in the literature, the widely used proxy for long-term interest rates is the T-bond rates. So, we do the same because of the following two major reasons: i) T-bond rate is a relatively better indicator of the long-run interest rates compared to its rivals. In view of market depth, T-bond rate is seen a more credible indicator for interest rates in the economy relative to their alternatives, such as deposit or loan rates. Because T-bond rates are more sensitive to economic and political developments at both national and international levels in relation to their rivals. However, deposit or loan rates, in contrast to T-bond rates, do not show an immediate reaction to economic and political changes in the economy, creating timeinconsistency problem; ii) harmonized data availability for the sample countries.

Our second variable is inflation $(\pi)$. Herein, $\pi$ refers to consumer price index inflation that is proxied for the expected rate of inflation. As is known, inflationary expectations are not easy to observe directly. So, in parallel to the available literature, we consider the actual rate of inflation as the proxy of the expected rate of inflation. By doing so, we try to overcome the unavailability of data on the expected rates of inflation that is essential to estimate the original form of the Fisher hypothesis. In this regard, we follow Barsky (1987) and estimate the ex-post Fisher hypothesis, rather than its original form proposed by Fisher (1930), that refers to a correlation between nominal interest rates and realized inflation. That is different from the ex-ante Fisher hypothesis that denotes an unobservable relationship between nominal rates and underlying expected inflation. As is well-known, the rate of the changes in consumer price inflation refers to the inflation rate. Accordingly, we measure the actual inflation rate as the monthly percentage changes in the actual consumer price index over the previous month.

Our third, the final, variable is the exchange rate. In this study, we take into account nominal effective exchange rate (NEER) as proxy variable for exchange rate. This is because the NEER is an index denoting the value of a country's currency in relation to major foreign currencies, such as the US dollar and the Euro. The index represents a weighted average of foreign currencies by their share in trade volume. ${ }^{8}$

The summary statistics of the variables and the line graphs on the relationship of interest rates, inflation, and exchange rates trend for the sample countries are depicted in Table 1 and Figure 1 , respectively.

\footnotetext{
${ }^{7}$ Working with monthly time series data, for instance, rather than annual data, can be justified on the ground that using annual data may lead to the aggregation-biased problem as argued by Rossana and Seater (1995). One plausible way to overcome this problem is to study with monthly data as suggested by Berument and Jelassi (2002). Following the suggestions in Berument and Jelassi (2002), in this study, we work with the available highest frequency data, monthly data, instead of lower frequency data, such as quarterly and annual data.

${ }^{8}$ NEER index helps us to understand the pass-through effect of an import-dependent country. The NEER index is also useful in analyzing the relationship between interest rates and exchange rates. It determines not only the trade competitiveness of a country, but also influences interest rates through monetary policy.
} 
Table 1. Summary statistics for the sample countries

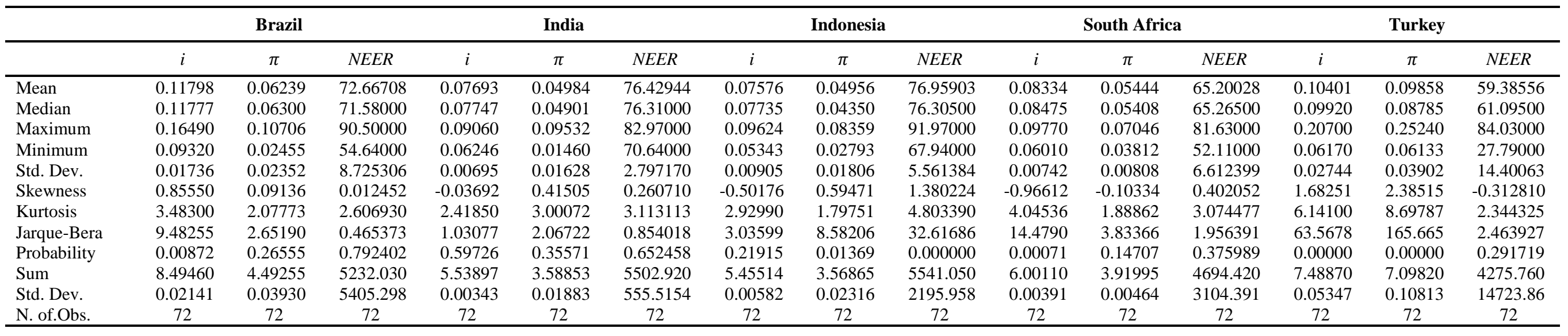

Note: In the table, $i$ stands for the nominal interest rate, $\pi$ for the inflation rate, and NEER for the exchange rate, respectively. 
Figure 1. The line graphs of variables for the sample countries, 2013:1-2018:12

\section{Brazil}

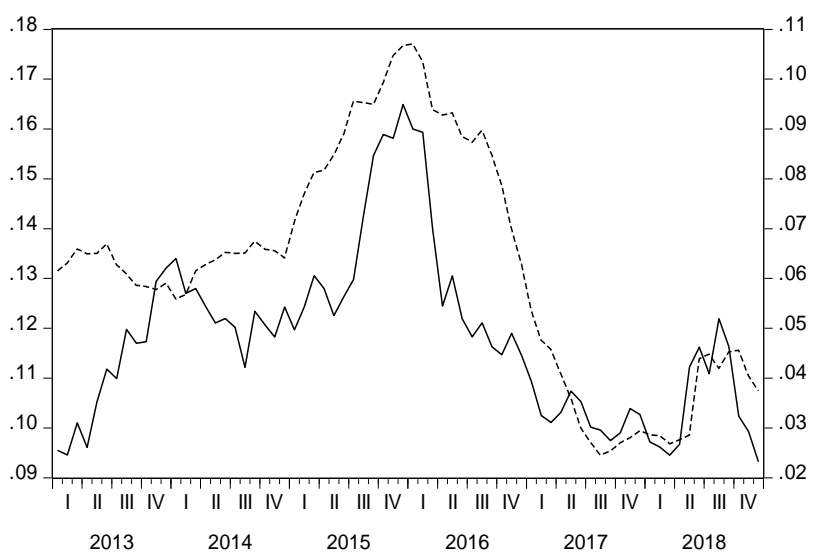

- Interest rate ---- Inflation
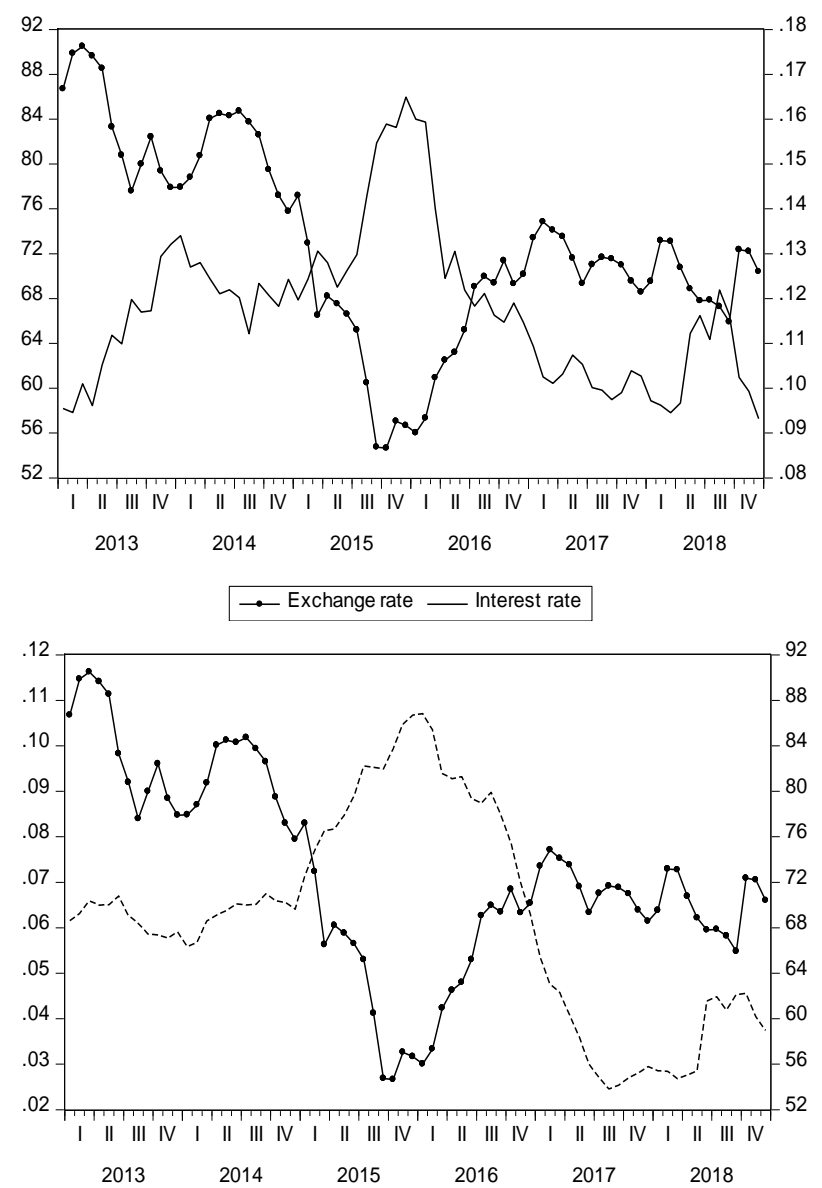

---- Inflation $\rightarrow-$ Exchange rate
India

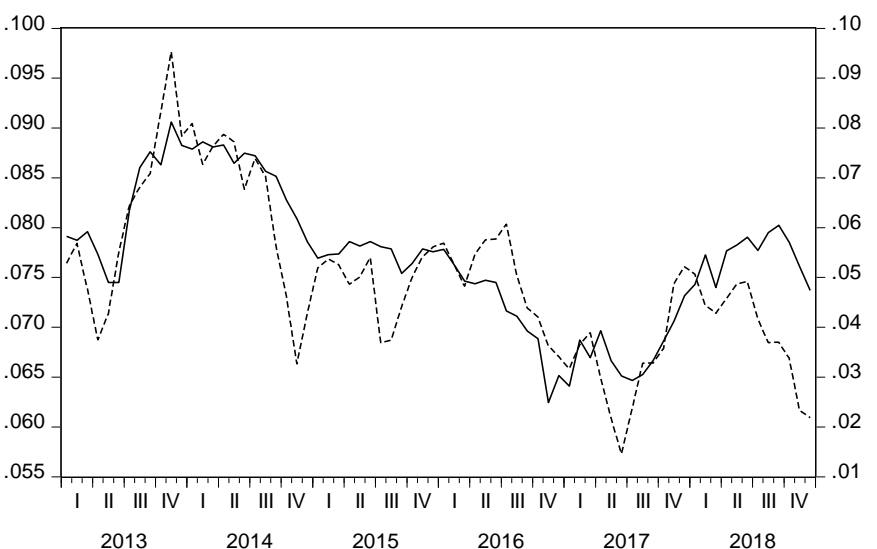

- Interest rate ---- Inflation
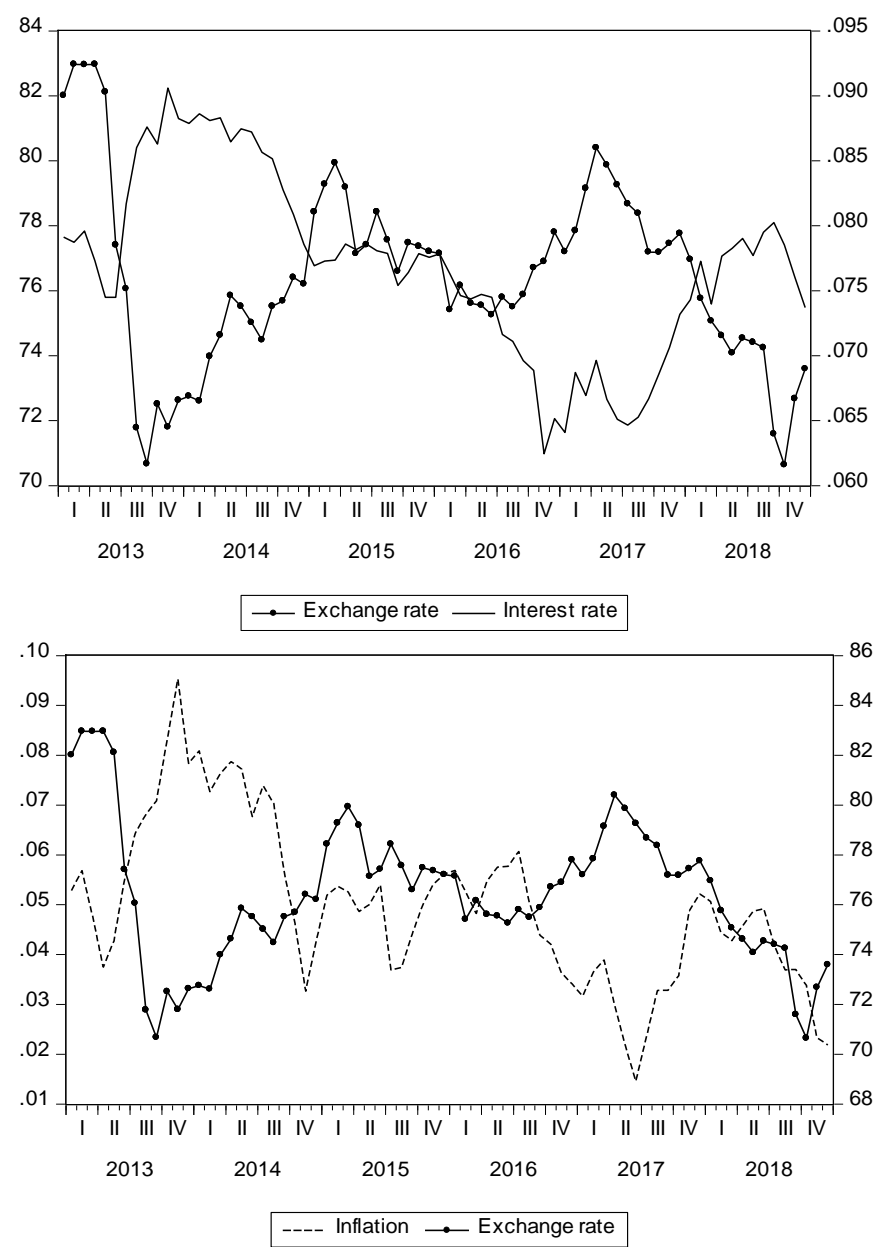
Figure 1: continued ...

Indonesia

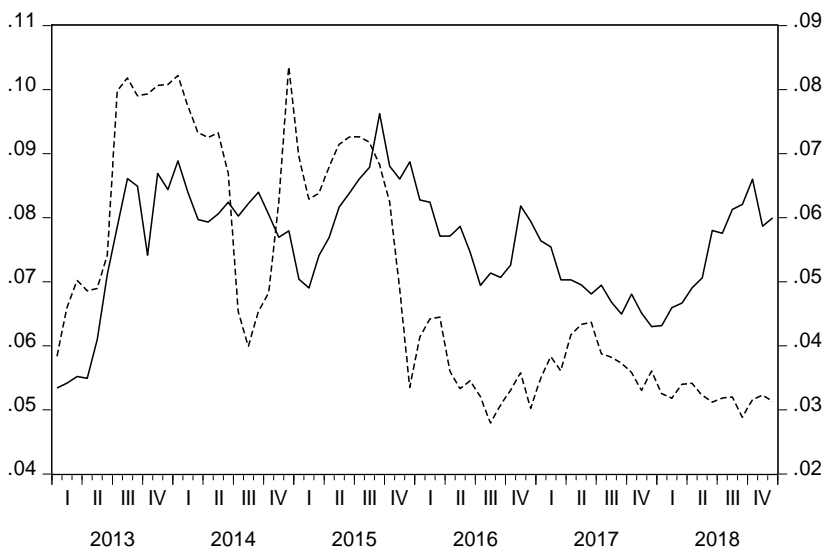

- Interest rate ---- Inflation

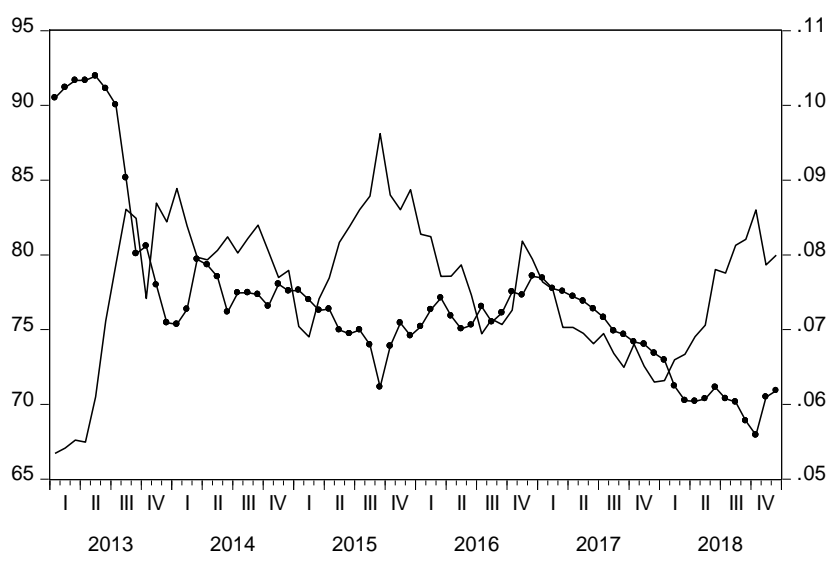

$\longrightarrow$ Exchange rate — Interest rate

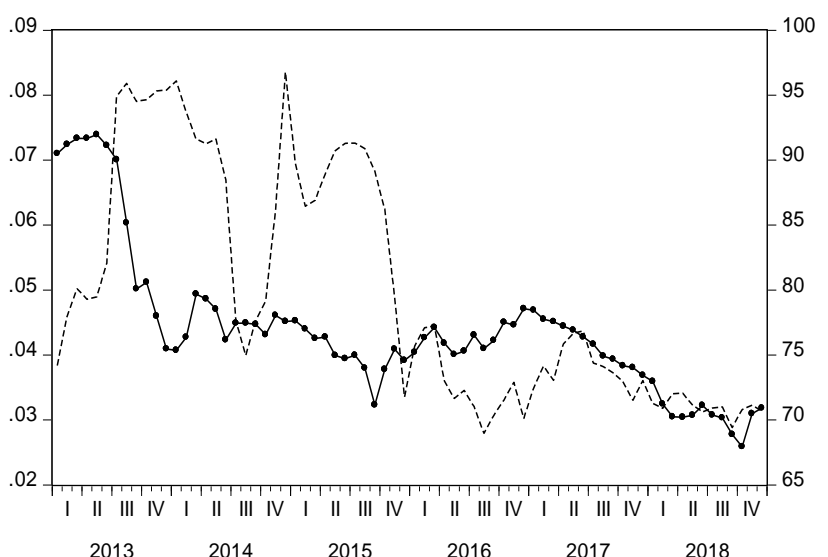

---- Inflation $\rightarrow$ Exchange rate
South Africa

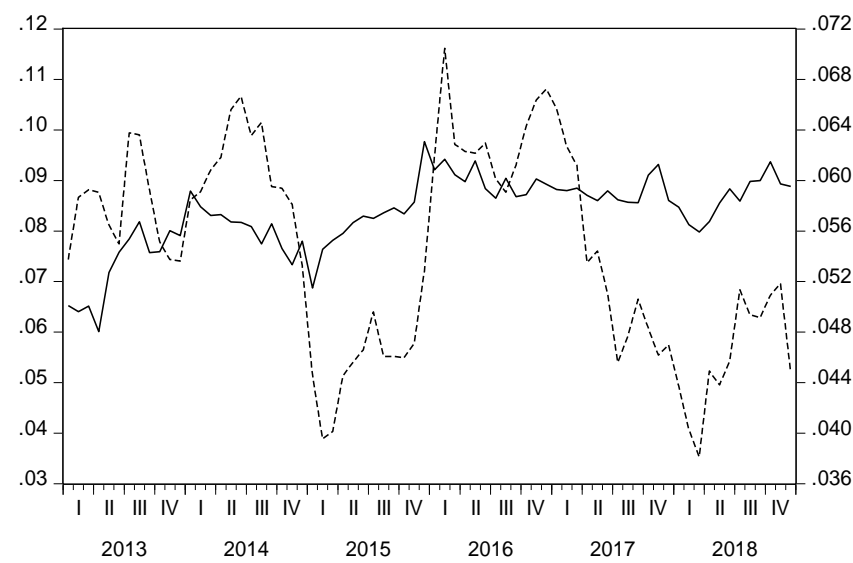

- Interest rate ---- Inflation
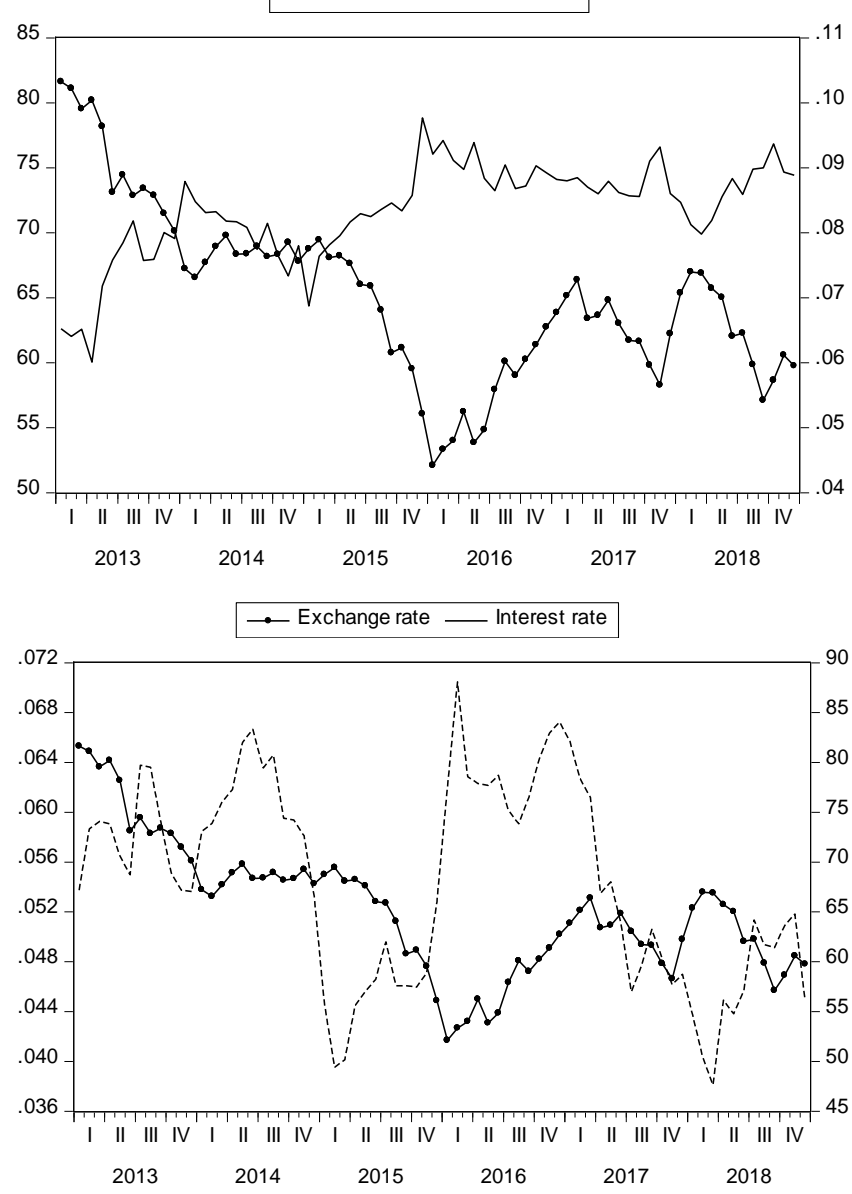

---- Inflation $\rightarrow$ Exchange rate 
Figure 1: continued ...

\section{Turkey}
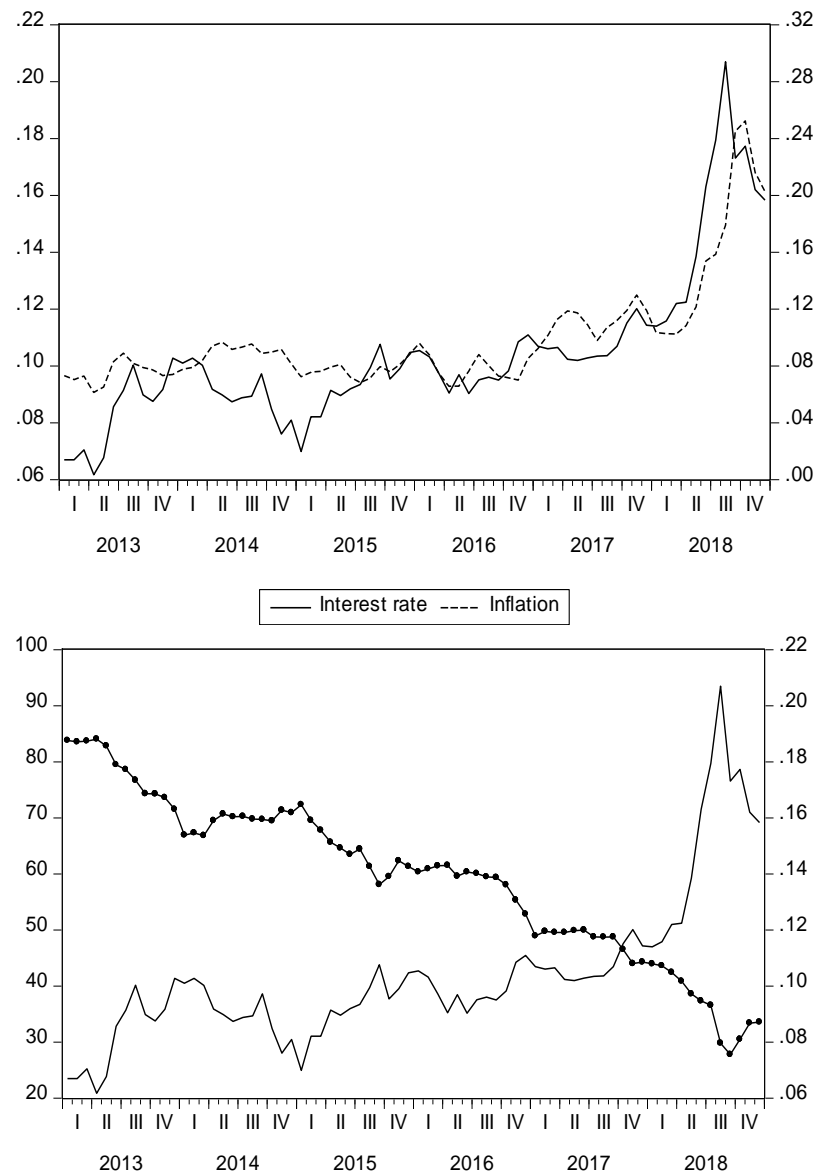

$\rightarrow$ Exchange rate — Interest rate

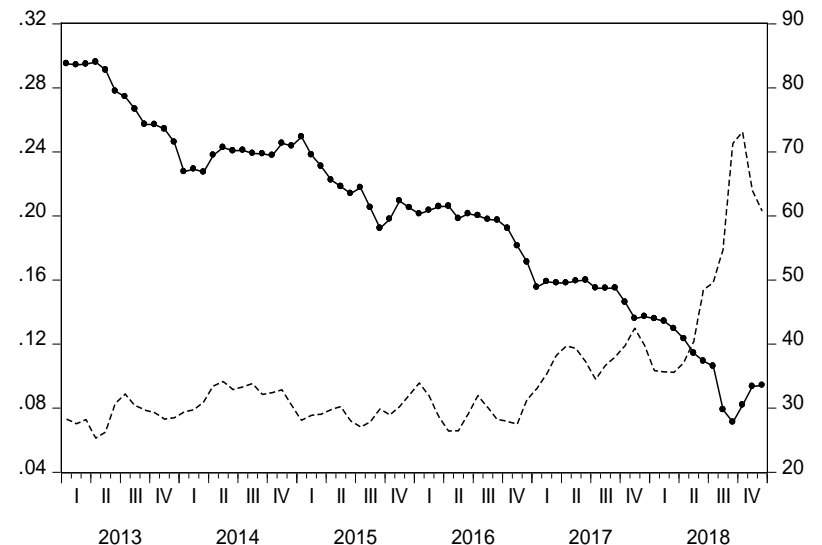

$\begin{array}{llllll}2013 & 2014 & 2015 & 2016 & 2017 & 2018\end{array}$

---- Inflation $\rightarrow$ Exchange rate 


\subsection{Model: Le and Lee's (2010) ADL test for threshold cointegration}

Utilizing Li and Lee's (2010) ADL tests for threshold cointegration, in this study, we investigate the possible existence of the long-run interrelationships between interest rates, inflation, and exchange rates in five fragile emerging market economies. The major advantage of $\mathrm{Li}$ and Lee's (2010) test is that, as pointed out by Pan et al. (2012), it allows researchers to investigate non-linearity and cointegration simultaneously.

By this way, the present study intends to fill out the existing gap in the current literature. To the best of our knowledge, this study is the first of its kind to utilize the ADL test for threshold cointegration in examining the long-run interrelationships between interest rates, inflation, and exchange rates, at least, for the countries under scrutiny. This econometric technique yields possible to test the presence of cointegrating relationship without requiring the same order of integration of all variables (Chang and $\mathrm{Xu}, 2012$ ). This superiority of the ADL technique allows us to avoid poor size and power properties of the conventional unit root tests as pointed out by Harris (1995). Additionally, it improves the loss of power frequently encountered in tests such as those tests presented by Engle and Granger (1987) and Johansen (1988) and helps us to diagnose the non-linearity such as threshold effect. What is more, the Li and Lee's (2010) test is that the cointegrating vector is not pre-specified which extends the linear ADL test to a nonlinear threshold model framework. Based on the explanations above, we can claim that the threshold ADL model is the appropriate econometric estimation method for our analysis.

To investigate the possible presence of long-run interrelationships between interest rates, inflation, and exchange rates, we establish Eq. (1), (2), and (3) respectively. Accordingly, Eq. (1) denotes the nexus between nominal interest rates and inflation, Eq. (2) denotes the nexus between nominal interest rates and nominal exchange rates, and Eq. (3) denotes the nexus between nominal exchange rates and inflation. In establishing these regression equations, we consider the trends in available literature on the topic. So, in line with the theoretical and empirical studies, a large body of which was explained in detail in Section 2, the regression equations that we propose to estimate in this study are as follows:

$$
\begin{aligned}
& \Delta i_{t}=\beta_{0}+\beta_{1} i_{t-1} I_{t}+\beta_{2} i_{t-1}\left(1-I_{t}\right)+\beta_{3} \pi_{t-1} I_{t}+\beta_{4} \pi_{t-1}\left(1-I_{t}\right)+\beta_{5} \Delta \pi_{t}+\beta_{6} \Delta i_{t-1} \\
&+\beta_{7} \Delta \pi_{t-1}+\varepsilon_{t} \\
& \begin{aligned}
\Delta i_{t}=\beta_{0} & +\beta_{1} i_{t-1} I_{t}+\beta_{2} i_{t-1}\left(1-I_{t}\right)+\beta_{3} N E E R_{t-1} I_{t}+\beta_{4} N E E R_{t-1}\left(1-I_{t}\right)+\beta_{5} \Delta N E E R_{t} \\
& +\beta_{6} \Delta i_{t-1}+\beta_{7} \Delta N E E R_{t-1}+\varepsilon_{t} \\
\Delta N E E R_{t}= & \beta_{0}+\beta_{1} N E E R_{t-1} I_{t}+\beta_{2} N E E R_{t-1}\left(1-I_{t}\right)+\beta_{3} \pi_{t-1} I_{t}+\beta_{4} \pi_{t-1}\left(1-I_{t}\right)+\beta_{5} \Delta \pi_{t} \\
& +\beta_{6} \Delta N E E R_{t-1}+\beta_{7} \Delta \pi_{t-1}+\varepsilon_{t}
\end{aligned}
\end{aligned}
$$

where $i$ denotes T-bond rates as a proxy for the nominal interest rates, $\pi$ is the actual inflation rates as a proxy for the expected rate of inflations, NEER is the nominal effective exchange rate as a proxy for the exchange rate, $I_{t}$ is the indicator function.

$\mathrm{Li}$ and Lee (2010) suggest two indicators: Indicator A with $I_{t}^{A}=\mathrm{I}\left(e_{t-1}<e_{t-1}^{*}(\tau)\right)$ and Indicator $\mathrm{B}$ with $I_{t}^{B}=\mathrm{I}\left(\Delta e_{t-1}<\Delta e_{t-1}^{*}(\tau)\right) . e_{t}^{*}(\tau)$ stand for the threshold value. Here, $\tau$ can be viewed as the $\tau$ th percentile of the empirical distribution of $e_{t-1}$ or $\Delta e_{t-1}$ and $\tau$ is obtained by maximizing the test statistic for the null hypothesis between the lower and upper $15 \%$ percentiles of the sorted series $e_{t-1}$ or $\Delta e_{t-1}$. There is no prescribed rule regarding the choice of the indicator in the three regression equations presented above. Adjustment speed towards 
the long-run equilibrium, which is measured by $\beta_{i}(\mathrm{i}=1 \sim 4)$, is allowed to vary in the threshold model. Thus, the conventional ADL model is a special form of the threshold ADL model. Here, the lag selection is guided by the partial autocorrelation function of $\Delta i_{t}, \Delta \pi_{t}$ and $\Delta N E E R_{t}$.

Li and Lee (2010) propose two alternative tests for threshold cointegration. The first test is the BO-type test which was developed by Boswijk (1994) that suggests testing the coefficients of $i_{t-1}, \pi_{t-1}$ and $N E E R_{t-1}$. The null hypothesis of no threshold cointegration for the BO-type test can be written as follows:

$H_{0}: \beta_{1}=\beta_{2}=\beta_{3}=\beta_{4}=0$

Conversely, the second test is the BDM-type test which was developed by Banerjee et al. (1998) that suggests adding lead of $i_{t-1}, \pi_{t-1}$, and $N E E R_{t-1}$ to their regression so that the asymptotic results are valid in the absence of strict exogeneity. The threshold BDM test is based on testing following null hypothesis:

$H_{0}: \beta_{1}=\beta_{2}=0$

$\mathrm{Li}$ and Lee (2010), based on their Monte Carlo experiment, indicated that the BO test performs better than any of its rivals in terms of both size and power. Given this, we take into consideration the BO threshold cointegration test in the present study. However, it is important to note here that there is no generally prescribed rule as to whether to use Indicator A or B in the Li and Lee's (2010) model. In this regard, Lu et al. (2012) recommend selecting an adjustment mechanism by using a model selection criterion such as the Akaike Information Criteria (AIC) or Schwartz Criteria (SC). Here, only one lag of our variables $-\Delta \mathrm{i}_{\mathrm{t}}, \Delta \pi_{t}$ and $\Delta N E E R_{\mathrm{t}}-$ are included to our regression equations presented above by following the parsimony principle. Critical rules that will be taken into account for different circumstances are illustrated by Li and Lee (2010).

\section{Results and Justification}

Tables 2 through 4 present the results of the ADL test for threshold cointegration using Indicator A and Indicator B functions, respectively. The results obtained from Eq. 1 are tabulated in Table 2. As we also noted earlier, there is generally no prescribed rule as to whether Indicator A or $\mathrm{B}$ is used in our model. Now then, the recommendation is to select the adjustment mechanism using a model selection criterion such as the AIC or SC.

The appropriate indicator for the ADL test for threshold cointegration is determined by means of the Akaike information criterion (AIC) as suggested by Liu et al. (2012) and Chang et al. (2012). If the AIC is chosen, as we do in this study, the ADL model with Indicator B is favored in all of the country cases except Indonesia. In other words, referencing to the results reported in Table 2, we can safely argue that indicator B is appropriate for four sample countries: Brazil, India, South Africa, and Turkey. The BO test statistics are bigger than their critical values, thus rejecting the null hypothesis at the $1 \%, 5 \%$, and $10 \%$ levels or at a better level of statistical significance. All these imply that interest rates and the actual inflation rates move together. More specifically, it seems that the ADL test which we employed in this study provides evidence in favor of the long-run validity of the interest rates-inflation nexus for all the sample countries except Indonesia. 
Turning to Table 3, it reports the results obtained from Eq. 2. As seen in the table, indicator A is not appropriate for the sample countries. However, indicator B is relevant for three out of five sample countries, Brazil, India, and Turkey. For the three sample countries, the BO test statistics are higher than their critical values, thus rejecting the null hypothesis at the $10 \%$ or better of statistical significance level. This means that there is a co-movement between interest rates and exchange rates just for three sample countries: Brazil, India, and Turkey.

Table 4 presents the results obtained from Eq. 3. It is significant from the BO test statistics that the null hypothesis of no threshold cointegration is rejected in the case of all the countries under scrutiny. In other words, the threshold cointegration relationships between exchange rates proxied by nominal effective exchange rates and inflation exist. The significant coefficients of $\beta_{i}(\mathrm{i}=1 \sim 4)$ indicate that the long-run adjustment process towards its equilibrium is asymmetric. All these results imply that exchange rates are positively associated with inflation in the sample countries without exception.

The results above clearly indicate that monthly data on the sampling countries for the observation period tends to support the validity of the ex-post Fisher hypothesis for the whole sample countries. Put it more differently, our empirical results corroborate the view that changes in the actual inflation rates, a proxy for the expected rate of inflation, lead to an equivalent change in the nominal interest rates in the long run. At this point, it is important to stress that this result is compatible with several earlier empirical studies conducted on the same topic [see, inter alia, Mishkin (1992), Crowder and Hoffman (1996), Westerlund (2007)]. On the other hand, from a macroeconomic policy viewpoint, our results related to the Fisher hypothesis imply that in the sample countries, real interest rates are not affected by monetary policy. This is to say that monetary authorities' actions do not exert any effect on real interest rates in the sample countries during the period on which we studied.

However, our sample data produces conflicting results about the long-run interest rates and exchange rates nexus. Simply put, the results we obtained display that there is a cointegrating relationship between interest rates and exchange rates for only three sample countries: Brazil, India, and Turkey. However, such a relationship does not exist for the remaining two countries, Indonesia and South Africa. These conflicting results may be attributed to the country-specific factors. Out of five sample countries, three countries (Brazil, India, and Turkey) have higher private sector debt denominated in foreign currency vis-a-vis the other two. So, in these countries, the long-run relationship between interest rates and exchange rates is more obvious. A good example of this is Turkey. When the Turkish lira depreciates against major currencies, Tbond rates are likely to go up as a result of increased risks. This is because market players start to launch to sell out Turkish T-bonds in contemplation of that Turkey would suffer from defaulting its foreign exchange liabilities. Ultimately, these developments will end up with an increase in the Turkish T-bond rates. The second possible argument that verifies the link between interest rates and exchange rates as shown in some sample countries may be explained in the context of the Feldstein chain - that is, an important explanation of the twin deficits phenomenon (see Feldstein, 1986). The Feldstein chain argues that under the floating exchange rate regime, in an open economy, persistently widening government deficits financed through domestic borrowing push the interest rates up and then increasing interest rates creates an attractive environment for foreign capital inflows. And then, increases in net foreign capital inflows, other things being equal, cause the local currency to appreciate driving trade balance into deficit. Schematically, the Feldstein can be described as follows: 
Government budget deficits $\uparrow \Rightarrow$ Government's deficit-financing requirement $\uparrow \Rightarrow$ Domestic interest rates $\uparrow \Rightarrow$ Foreign capital influx $\uparrow \Rightarrow$ Local currency appreciation $\uparrow \Rightarrow$ Worsening trade balance $\uparrow \Rightarrow \mathrm{NX} \downarrow$

Depending upon the circumstances of an individual country, a reverse Granger-causality between government budget deficits and trade deficits are also likely to occur. In such a case, the Feldstein chain will work reversely and then trade deficits would lead to budget deficits. This is because expansionary fiscal policies are more responsive to foreign trade shocks than budgetary shocks are. If so, expansionary fiscal policies would cause an appreciation of the local currency against foreign currencies, which in turn worsens the trade balance and thereby government budget balance.

On the other hand, our empirical results suggest that there exist a cointegrating relationship between the two variables for all these countries under scrutiny. Put in economic terms: exchange rates and inflation move together in the long-run in the sample countries. These results not only fully match with the theoretical expectations but also consistent with the most of previous empirical studies [see, e.g., Choudhri and Hakura (2006), Ca'Zorzi et al. (2007), Arslaner et al. (2014), among many others]. As also mentioned earlier, the sample countries are a total of five fragile EMEs. Broadly speaking, all of these countries are the countries with persistent current account deficits. At the same time, these countries are import-dependent countries. Therefore, it is expected that increases in the value of major trading countries' currencies against their local currencies will raise the prices of imported goods, resulting in an increase in domestic prices and, by implication, inflation. 
Table 2. ADL test results for the threshold cointegration: Eq. 1

\begin{tabular}{|c|c|c|c|c|c|c|c|}
\hline \multicolumn{8}{|c|}{ Brazil } \\
\hline \multicolumn{8}{|c|}{ Part A: Indicator A $\left(I_{t}^{A}\right)$} \\
\hline$\beta_{0}$ & $\beta$ & $\beta_{2}$ & $\beta_{3}$ & $\beta_{4}$ & $\beta_{5}$ & $\beta_{6}$ & $\beta_{7}$ \\
\hline-0.020 & 0.110 & -0.247 & 5.158 & 18.903 & 0.059 & -0.016 & 7.603 \\
\hline$(-1.043)$ & $(0.229)$ & $(-1.229)$ & $(0.335)$ & $(2.210)$ & (1.573) & $(-0.005)$ & (2.139) \\
\hline $\mathrm{BO}=$ & 5.618 & $e_{t^{*}}(\tau)=$ & 0.160 & $\tau=$ & 0.330 & $\mathrm{AIC}=$ & -1.127 \\
\hline \multicolumn{8}{|c|}{ Part B: Indicator B $\left(I_{t}^{B}\right)$} \\
\hline 0.0480 & -0.051 & -0.430 & 13.620 & 3.405 & 1.238 & -0.803 & -3.694 \\
\hline$(0.0211)$ & $(-5.229)$ & $(-2.110)$ & $(5.602)$ & $(1.770)$ & $(1.168)$ & $(-1.572)$ & $(-2.337)$ \\
\hline $\mathrm{BO}=$ & $27.709 *$ & $e_{t^{*}}(\tau)=$ & -0.160 & $\tau=$ & 0.779 & $\mathrm{AIC}=$ & -1.026 \\
\hline \multicolumn{8}{|c|}{ India } \\
\hline \multicolumn{8}{|c|}{ Part A: Indicator A $\left(I_{t}^{A}\right)$} \\
\hline$\beta_{0}$ & $\beta_{1}$ & $\beta_{2}$ & $\beta_{3}$ & $\beta_{4}$ & $\beta_{5}$ & $\beta_{6}$ & $\beta_{7}$ \\
\hline-0.4677 & 0.001 & -1.395 & 7.362 & 25.521 & 3.806 & 0.903 & -4.290 \\
\hline$(-1.1170)$ & $(0.074)$ & $(-1.772)$ & (1.809) & $(0.689)$ & $(0.227)$ & (1.504) & $(-1.745)$ \\
\hline $\mathrm{BO}=$ & 8.779 & $e_{t^{*}}(\tau)=$ & 0.552 & $\tau=$ & 0.093 & $\mathrm{AIC}=$ & -0.873 \\
\hline \multicolumn{8}{|c|}{ Part B: Indicator B $\left(I_{t}^{B}\right)$} \\
\hline-0.2380 & 0.336 & -0.221 & 9.167 & 7.205 & 4.706 & 0.693 & -5.360 \\
\hline$(-0.227)$ & $(0.680)$ & $(-3.047)$ & $(2.391)$ & (1.429) & $(1.046)$ & $(0.836)$ & $(-1.447)$ \\
\hline $\mathrm{BO}=$ & $13.228 * * *$ & $e_{t^{*}}(\mathcal{\tau})=$ & -0.118 & $\tau=$ & 0.558 & $\mathrm{AIC}=$ & 1.228 \\
\hline \multicolumn{8}{|c|}{ Indonesia } \\
\hline \multicolumn{8}{|c|}{ Part A: Indicator A $\left(I_{t}^{A}\right)$} \\
\hline$\beta_{0}$ & $\beta$ & $\beta_{2}$ & $\beta_{3}$ & $\beta_{4}$ & $\beta_{5}$ & $\beta_{6}$ & $\beta_{7}$ \\
\hline 0.0480 & -0.227 & 0.338 & 3.662 & 5.621 & 1.451 & 0.903 & 3.146 \\
\hline$(0.018)$ & $(-1.004)$ & (1.369) & $(0.118)$ & $(0.880)$ & $(0.452)$ & (0.994) & $(0.773)$ \\
\hline $\mathrm{BO}=$ & 4.782 & $e_{t^{*}}(\tau)=$ & -1.903 & $\tau=$ & 1.228 & $\mathrm{AIC}=$ & -1.552 \\
\hline \multicolumn{8}{|c|}{ Part B: Indicator B $\left(I_{t}^{B}\right)$} \\
\hline 0.1033 & 0.449 & -0.338 & 1.057 & 5.442 & -0.809 & -0.904 & -1.004 \\
\hline$(0.5510)$ & (1.604) & $(-1.338)$ & $(0.558)$ & $(1.260)$ & $(-0.101)$ & $(-0.611)$ & $(-0.327)$ \\
\hline $\mathrm{BO}=$ & 7.431 & $e_{t^{*}}(\tau)=$ & -0.890 & $\tau=$ & 0.867 & $\mathrm{AIC}=$ & -0.375 \\
\hline \multicolumn{8}{|c|}{ South Africa } \\
\hline \multicolumn{8}{|c|}{ Part A: Indicator A $\left(I_{t}^{A}\right)$} \\
\hline$\beta_{0}$ & $\beta_{1}$ & $\beta_{2}$ & $\beta_{3}$ & $\beta_{4}$ & $\beta_{5}$ & $\beta_{6}$ & $\beta_{7}$ \\
\hline 0.036 & 0.045 & -0.683 & 1.984 & 0.793 & 1.962 & 1.832 & 0.227 \\
\hline (1.804) & $(2.763)$ & $(0.894)$ & $(1.052)$ & $(0.550)$ & $(0.220)$ & (3.532) & $(1.416)$ \\
\hline $\mathrm{BO}=$ & 4.842 & $e_{t^{*}}(\boldsymbol{\tau})=$ & 6.042 & $\tau=$ & 0.773 & $\mathrm{AIC}=$ & -0.558 \\
\hline \multicolumn{8}{|c|}{ Part B: Indicator B $\left(I_{t}^{B}\right)$} \\
\hline 0.118 & -0.560 & -0.314 & 1.025 & 5.228 & 0.573 & -0.730 & -2.016 \\
\hline$(1.666)$ & $(-0.528)$ & $(-0.335)$ & $(0.392)$ & $(2.503)$ & $(0.551)$ & $(0.068)$ & $(1.558)$ \\
\hline $\mathrm{BO}=$ & $15.688 * * *$ & $e_{t^{*}}(\mathcal{\tau})=$ & -0.277 & $\tau=$ & 0.038 & $\mathrm{AIC}=$ & -0.557 \\
\hline \multicolumn{8}{|c|}{ Turkey } \\
\hline \multicolumn{8}{|c|}{ Part A: Indicator A $\left(I_{t}^{A}\right)$} \\
\hline$\beta_{0}$ & $\beta_{1}$ & $\beta_{2}$ & $\beta_{3}$ & $\beta_{4}$ & $\beta_{5}$ & $\beta_{6}$ & $\beta_{7}$ \\
\hline 0.669 & 0.331 & 0.667 & 1.521 & -0.725 & -0.127 & -0.338 & 1.546 \\
\hline$(0.117)$ & $(0.217)$ & $(0.909)$ & $(0.549)$ & $(-0.325)$ & $(-0.224)$ & $(-0.331)$ & $(0.318)$ \\
\hline $\mathrm{BO}=$ & 7.603 & $e_{t^{*}}(\mathcal{\tau})=$ & 1.770 & $\tau=$ & 0.420 & $\mathrm{AIC}=$ & -0.965 \\
\hline \multicolumn{8}{|c|}{ Part B: Indicator B $\left(I_{t}^{B}\right)$} \\
\hline-0.668 & -0.335 & 0.340 & 2.023 & 3.519 & 6.440 & 3.449 & -6.278 \\
\hline$(-0.130)$ & $(-1.725)$ & $(0.539)$ & $(0.443)$ & (1.582) & (1.903) & $(0.664)$ & $(-2.027)$ \\
\hline $\mathrm{BO}=$ & $21.712 *$ & $e_{t^{*}}(\tau)=$ & -1.773 & $\tau=$ & 0.073 & $\mathrm{AIC}=$ & -1.478 \\
\hline
\end{tabular}

Notes: $\beta$ is the estimated coefficient of Eq. 1. The t-statistics for the variables are in parentheses. $e_{t^{*}}(\tau)$ is the threshold value. $\tau$ is the $\tau t h$ percentile of the empirical distribution of $e_{t-1}$ or $\Delta e_{t-1}$. The critical values for $\mathrm{BO}$ statistic are presented in $\mathrm{Li}$ and Lee (2010). For Indicator A, the critical values of BO test for 10\%, 5\% and 1\% are, 16.90, 19.04, and 24.00 , respectively. For Indicator B, the critical values of BO test for the statistical significance at $10 \%, 5 \%$ and $1 \%$ are, $16.36,18.66$, and 23.88 , respectively. $* * *$ and $* * *$ denote statistical significance at the $1 \%, 5 \%$, and $10 \%$ levels, respectively. 
Table 3. ADL test results for the threshold cointegration: Eq. 2

\begin{tabular}{|c|c|c|c|c|c|c|c|}
\hline \multicolumn{8}{|l|}{ Brazil } \\
\hline \multicolumn{8}{|c|}{ Part A: Indicator A $\left(I_{t}^{A}\right)$} \\
\hline$\beta_{0}$ & $\beta_{1}$ & $\beta_{0}$ & $\beta_{1}$ & $\beta_{0}$ & $\beta_{1}$ & $\beta_{0}$ & $\beta_{1}$ \\
\hline-0.071 & 0.476 & -0.118 & 0.336 & -1.279 & 0.504 & -0.559 & 0.562 \\
\hline$(-1.179)$ & $(0.925)$ & $(-0.552)$ & (1.667) & $(-1.229)$ & $(0.730)$ & $(-0.480)$ & (1.169) \\
\hline $\mathrm{BO}=$ & 6.331 & $e_{t^{*}}(\tau)=$ & 0.904 & $\tau=$ & 0.325 & $\mathrm{AIC}=$ & -1.441 \\
\hline \multicolumn{8}{|c|}{ Part B: Indicator B $\left(I_{t}^{B}\right)$} \\
\hline 0.4712 & -0.552 & 1.278 & -0.150 & 0.517 & -0.448 & 0.663 & -0.993 \\
\hline$(0.0415)$ & $(-1.737)$ & $(0.663)$ & $(-2.327)$ & $(0.775)$ & $(-4.620)$ & $(1.440)$ & $(-3.403)$ \\
\hline $\mathrm{BO}=$ & $37.031 *$ & $e_{t^{*}}(\tau)=$ & -1.559 & $\tau=$ & 0.763 & $\mathrm{AIC}=$ & -1.130 \\
\hline \multicolumn{8}{|c|}{ India } \\
\hline \multicolumn{8}{|c|}{ Part A: Indicator A $\left(I_{t}^{A}\right)$} \\
\hline$\beta_{0}$ & $\beta_{1}$ & $\beta_{2}$ & $\beta_{3}$ & $\beta_{4}$ & $\beta_{5}$ & $\beta_{6}$ & $\beta_{7}$ \\
\hline 0.331 & 0.983 & -0.487 & 0.325 & 0.559 & 0.364 & 0.571 & 0.893 \\
\hline$(0.661)$ & $(0.436)$ & $(-1.617)$ & $(0.552)$ & $(0.333)$ & $(0.633)$ & $(0.599)$ & $(0.233)$ \\
\hline $\mathrm{BO}=$ & 6.351 & $e_{t^{*}}(\mathcal{\tau})=$ & 4.904 & $\tau=$ & 0.673 & $\mathrm{AIC}=$ & -1.092 \\
\hline \multicolumn{8}{|c|}{ Part B: Indicator B $\left(I_{t}^{B}\right)$} \\
\hline 0.0618 & 1.063 & -0.784 & 0.428 & 0.164 & 0.403 & 0.157 & 0.824 \\
\hline$(0.6009)$ & $(0.082)$ & $(0.651)$ & $(0.178)$ & $(0.462)$ & $(1.745)$ & $(0.625)$ & (2.543) \\
\hline $\mathrm{BO}=$ & $31.754 *$ & $e_{t^{*}}(\tau)=$ & -0.830 & $\tau=$ & 0.150 & $\mathrm{AIC}=$ & -0.293 \\
\hline \multicolumn{8}{|c|}{ Indonesia } \\
\hline \multicolumn{8}{|c|}{ Part A: Indicator A $\left(I_{t}^{A}\right)$} \\
\hline$\beta_{0}$ & $\beta_{1}$ & $\beta_{2}$ & $\beta_{3}$ & $\beta_{4}$ & $\beta_{5}$ & $\beta_{6}$ & $\beta_{7}$ \\
\hline 0.051 & -0.227 & -0.372 & 0.947 & -0.372 & 0.138 & 0.342 & 0.774 \\
\hline$(0.043)$ & $(-0.173)$ & $(-0.652)$ & $(1.248)$ & $(-0.361)$ & $(0.362)$ & $(0.276)$ & $(0.453)$ \\
\hline $\mathrm{BO}=$ & 8.334 & $e_{t^{*}}(\tau)=$ & 0.438 & $\tau=$ & 0.164 & $\mathrm{AIC}=$ & -1.562 \\
\hline \multicolumn{8}{|c|}{ Part B: Indicator B $\left(I_{t}^{B}\right)$} \\
\hline 0.0452 & 0.433 & -0.438 & 0.822 & 0.625 & 0.356 & 0.504 & 0.620 \\
\hline$(0.3362)$ & $(0.193)$ & $(-0.244)$ & $(0.610)$ & (1.379) & $(0.481)$ & $(0.173)$ & $(0.463)$ \\
\hline $\mathrm{BO}=$ & 9.450 & $e_{t^{*}}(\tau)=$ & 0.432 & $\tau=$ & 0.501 & $\mathrm{AIC}=$ & 0.149 \\
\hline \multicolumn{8}{|c|}{ South Africa } \\
\hline \multicolumn{8}{|c|}{ Part A: Indicator A $\left(I_{t}^{A}\right)$} \\
\hline$\beta_{0}$ & $\beta_{1}$ & $\beta_{2}$ & $\beta_{3}$ & $\beta_{4}$ & $\beta_{5}$ & $\beta_{6}$ & $\beta_{7}$ \\
\hline 0.067 & 0.149 & 0.386 & 0.195 & 0.528 & 1.275 & -0.432 & -0.381 \\
\hline$(0.571)$ & $(0.234)$ & $(0.095)$ & $(0.144)$ & $(0.148)$ & $(0.276)$ & $(-0.310)$ & $(-0.302)$ \\
\hline $\mathrm{BO}=$ & 7.440 & $e_{t^{*}}(\tau)=$ & -0.126 & $\tau=$ & 0.179 & $\mathrm{AIC}=$ & -0.776 \\
\hline \multicolumn{8}{|c|}{ Part B: Indicator B $\left(I_{t}^{B}\right)$} \\
\hline 0.635 & 0.263 & 0.201 & 0.239 & 0.273 & -0.894 & -0.083 & 0.415 \\
\hline$(0.563)$ & $(0.483)$ & $(0.415)$ & $(1.802)$ & $(0.337)$ & $(-0.984)$ & $(-0.892)$ & $(0.431)$ \\
\hline $\mathrm{BO}=$ & 5.179 & $e_{t^{*}}(\tau)=$ & -0.867 & $\tau=$ & 0.403 & $\mathrm{AIC}=$ & -0.891 \\
\hline \multicolumn{8}{|c|}{ Turkey } \\
\hline \multicolumn{8}{|c|}{ Part A: Indicator A $\left(I_{t}^{A}\right)$} \\
\hline$\beta_{0}$ & $\beta_{1}$ & $\beta_{2}$ & $\beta_{3}$ & $\beta_{4}$ & $\beta_{5}$ & $\beta_{6}$ & $\beta_{7}$ \\
\hline 0.441 & 0.164 & 0.483 & 0.367 & 0.484 & 0.759 & 0.382 & 0.172 \\
\hline$(0.226)$ & $(0.071)$ & $(0.181)$ & $(0.250)$ & $(0.371)$ & $(0.035)$ & $(0.113)$ & $(0.173)$ \\
\hline $\mathrm{BO}=$ & 8.372 & & 0.371 & $\tau=$ & 0.153 & $\mathrm{AIC}=$ & -1.221 \\
\hline \multicolumn{8}{|c|}{ Part B: Indicator B $\left(I_{t}^{B}\right)$} \\
\hline 0.0722 & 0.263 & 0.473 & 0.452 & 0.460 & 0.258 & 0.234 & 0.137 \\
\hline$(0.407)$ & $(0.356)$ & $(0.392)$ & $(0.195)$ & $(0.395)$ & $(0.270)$ & $(0.225)$ & $(0.181)$ \\
\hline $\mathrm{BO}=$ & $22.016^{*}$ & $e_{t^{*}}(\mathcal{\tau})=$ & 0.287 & $\tau=$ & 0.187 & $\mathrm{AIC}=$ & -0.331 \\
\hline
\end{tabular}

Notes: $\beta$ is the estimated coefficient of Eq. 2. The t-statistics for the variables are in parentheses. $e_{t^{*}}(\tau)$ is the threshold value. $\tau$ is the $\tau t h$ percentile of the empirical distribution of $e_{t-1}$ or $\Delta e_{t-1}$. The critical values for $\mathrm{BO}$ statistic are presented in $\mathrm{Li}$ and Lee (2010). For Indicator A, the critical values of BO test for 10\%, 5\% and 1\% are, 16.90, 19.04, and 24.00 , respectively. For Indicator B, the critical values of BO test for the statistical significance at $10 \%, 5 \%$ and $1 \%$ are, 16.36, 18.66, and 23.88, respectively. $* * *$ and $* * *$ denote statistical significance at the $1 \%, 5 \%$, and $10 \%$ levels, respectively. 
Table 4. ADL test results for the threshold cointegration: Eq. 3

\begin{tabular}{|c|c|c|c|c|c|c|c|}
\hline \multicolumn{8}{|l|}{ Brazil } \\
\hline \multicolumn{8}{|c|}{ Part A: Indicator A $\left(I_{t}^{A}\right)$} \\
\hline$\beta_{0}$ & $\beta_{1}$ & $\beta_{2}$ & $\beta_{3}$ & $\beta_{4}$ & $\beta_{5}$ & $\beta_{6}$ & $\beta_{7}$ \\
\hline 0.049 & 0.447 & 0.277 & 0.629 & 0.015 & 0.359 & 0.278 & 0.195 \\
\hline$(0.338)$ & $(0.462)$ & $(0.083)$ & $(0.074)$ & $(0.364)$ & $(0.146)$ & $(0.316)$ & $(0.460)$ \\
\hline $\mathrm{BO}=$ & 6.802 & $e_{t^{*}}(\tau)=$ & 0.367 & $\tau=$ & 0.047 & $\mathrm{AIC}=$ & -0.742 \\
\hline \multicolumn{8}{|c|}{ Part B: Indicator B $\left(I_{t}^{B}\right)$} \\
\hline 0.036 & 0.176 & 0.416 & 0.487 & 1.384 & 0.772 & 0.286 & 0.346 \\
\hline$(0.014)$ & $(0.206)$ & $(0.305)$ & $(0.175)$ & $(0.407)$ & $(0.463)$ & 0.572 & 0.473 \\
\hline $\mathrm{BO}=$ & $12.709 * * *$ & $e_{t^{*}}(\boldsymbol{\tau})=$ & 0.079 & $\tau=$ & 0.321 & $\mathrm{AIC}=$ & -0.895 \\
\hline \multicolumn{8}{|c|}{ India } \\
\hline \multicolumn{8}{|c|}{ Part A: Indicator A $\left(I_{t}^{A}\right)$} \\
\hline$\beta_{0}$ & $\beta_{1}$ & $\beta_{2}$ & $\beta_{3}$ & $\beta_{4}$ & $\beta_{5}$ & $\beta_{6}$ & $\beta_{7}$ \\
\hline 0.094 & 0.279 & 0.337 & 0.470 & 0.273 & 0.501 & 0.194 & 0.094 \\
\hline$(0.004)$ & $(0.223)$ & $(0.370)$ & $(0.422)$ & $(0.601)$ & $(0.469)$ & $(0.012)$ & $(0.503)$ \\
\hline $\mathrm{BO}=$ & 7.951 & $e_{t^{*}}(\tau)=$ & 0.447 & $\tau=$ & 0.228 & $\mathrm{AIC}=$ & -0.935 \\
\hline \multicolumn{8}{|c|}{ Part B: Indicator B $\left(I_{t}^{B}\right)$} \\
\hline 0.277 & 0.490 & 0.480 & 0.276 & 0.518 & 0.332 & -0.405 & -0.701 \\
\hline$(0.2280)$ & $(0.447)$ & $(0.226)$ & $(0.094)$ & $(0.447)$ & $(0.412)$ & $(-0.370)$ & $(-0.268)$ \\
\hline $\mathrm{BO}=$ & $19.704 * * *$ & $e_{t^{*}}(\tau)=$ & 0.450 & $\tau=$ & 0.236 & $\mathrm{AIC}=$ & -0.927 \\
\hline \multicolumn{8}{|c|}{ Indonesia } \\
\hline \multicolumn{8}{|c|}{ Part A: Indicator A $\left(I_{t}^{A}\right)$} \\
\hline$\beta_{0}$ & $\beta_{1}$ & $\beta_{2}$ & $\beta_{3}$ & $\beta_{4}$ & $\beta_{5}$ & $\beta_{6}$ & $\beta_{7}$ \\
\hline 0.071 & 0.337 & 0.225 & 0.489 & 0.0169 & 0.390 & 0.445 & 0.194 \\
\hline$(0.082)$ & $(1.278)$ & $(1.632)$ & $(0.011)$ & $(0.025)$ & $(0.080)$ & $(0.457)$ & $(0.240)$ \\
\hline $\mathrm{BO}=$ & 6.809 & $e_{t^{*}}(\tau)=$ & 0.011 & $\tau=$ & 0.083 & $\mathrm{AIC}=$ & 0.195 \\
\hline \multicolumn{8}{|c|}{ Part B: Indicator B $\left(I_{t}^{B}\right)$} \\
\hline 0.025 & -0.574 & -0.851 & 0.918 & 0.001 & -0.801 & 0.017 & 0.225 \\
\hline$(0.0980)$ & $(-0.085)$ & $(-0.112)$ & $(0.550)$ & $(0.072)$ & $(-0.262)$ & $(0.304)$ & $(0.073)$ \\
\hline $\mathrm{BO}=$ & $15.549 * * *$ & $e_{t^{*}}(\tau)=$ & 0.332 & $\tau=$ & 0.424 & $\mathrm{AIC}=$ & -0.894 \\
\hline \multicolumn{8}{|c|}{ South Africa } \\
\hline \multicolumn{8}{|c|}{ Part A: Indicator A $\left(I_{t}^{A}\right)$} \\
\hline$\beta_{0}$ & $\beta_{1}$ & $\beta_{2}$ & $\beta_{3}$ & $\beta_{4}$ & $\beta_{5}$ & $\beta_{6}$ & $\beta_{7}$ \\
\hline 0.277 & 0.412 & 0.668 & 0.503 & 0.125 & -0.506 & -0.407 & -0.809 \\
\hline$(0.446)$ & $(0.604)$ & $(0.553)$ & $(0.159)$ & $(0.122)$ & $(-0.360)$ & $(-0.406)$ & $(-0.711)$ \\
\hline $\mathrm{BO}=$ & 8.609 & $e_{t^{*}}(\tau)=$ & 0.336 & $\tau=$ & 0.079 & $\mathrm{AIC}=$ & -0.890 \\
\hline \multicolumn{8}{|c|}{ Part B: Indicator B $\left(I_{t}^{B}\right)$} \\
\hline 0.006 & 0.558 & 0.336 & 0.116 & 0.604 & 0.501 & 0.347 & 0.153 \\
\hline 0.040 & 0.335 & 0.208 & 0.664 & 0.351 & 0.401 & 0.223 & 0.601 \\
\hline $\mathrm{BO}=$ & $29.553 *$ & $e_{t^{*}}(\tau)=$ & 01180 & $\tau=$ & 0.150 & $\mathrm{AIC}=$ & 0.065 \\
\hline \multicolumn{8}{|c|}{ Turkey } \\
\hline \multicolumn{8}{|c|}{ Part A: Indicator A $\left(I_{t}^{A}\right)$} \\
\hline$\beta_{0}$ & $\beta_{1}$ & $\beta_{2}$ & $\beta_{3}$ & $\beta_{4}$ & $\beta_{5}$ & $\beta_{6}$ & $\beta_{7}$ \\
\hline 0.176 & 0.557 & 0.032 & 0.278 & -0.017 & 0.179 & 0.136 & 0.301 \\
\hline 0.337 & 0.227 & 0.036 & 0.015 & -0.084 & 0.065 & 0.116 & 0.336 \\
\hline $\mathrm{BO}=$ & 9.558 & $e_{t^{*}}(\tau)=$ & 0.036 & $\tau=$ & 0.175 & $\mathrm{AIC}=$ & 0.891 \\
\hline \multicolumn{8}{|c|}{ Part B: Indicator B $\left(I_{t}^{B}\right)$} \\
\hline 0.067 & 0.158 & -0.143 & 0.336 & 0.087 & 0.064 & 0.674 & 0.179 \\
\hline 0.0046 & 0.116 & -0.325 & 0.168 & 0.349 & 0.156 & 0.406 & 0.305 \\
\hline $\mathrm{BO}=$ & $32.709 *$ & $e_{t^{*}}(\mathcal{\tau})=$ & 0.096 & $\tau=$ & 0.052 & $\mathrm{AIC}=$ & 0.936 \\
\hline
\end{tabular}

Notes: $\beta$ is the estimated coefficient of Eq. 3. The t-statistics for the variables are in parentheses. $e_{t^{*}}(\tau)$ is the threshold value. $\tau$ is the $\tau t h$ percentile of the empirical distribution of $e_{t-1}$ or $\Delta e_{t-1}$. The critical values for $\mathrm{BO}$ statistic are presented in $\mathrm{Li}$ and Lee (2010). For Indicator A, the critical values of BO test for 10\%, 5\% and 1\% are, 16.90, 19.04, and 24.00 , respectively. For Indicator B, the critical values of BO test for the statistical significance at $10 \%, 5 \%$ and $1 \%$ are, 16.36, 18.66, and 23.88, respectively. $*^{* *}$ and $* * *$ denote statistical significance at the $1 \%, 5 \%$, and $10 \%$ levels, respectively. 


\section{Summary and conclusions}

In this study, we investigated whether there are the long-run interrelationships between interest rates, inflation, and exchange rates in five emerging market economies (Brazil, India, Indonesia, South Africa, and Turkey), what is so-called the fragile five, using monthly data ranging from January 2013 to December 2018. To this end, we employed Li and Lee's (2010) ADL test for threshold cointegration.

The study arrived at, overall, the following results: First, the sample countries' monthly time series data verify the validity of the ex-post Fisher hypothesis for the sample countries. Accordingly, changes in the actual inflation rate, which we used as a proxy for the expected rate of inflation, lead to a one-to-one change in nominal interest rates in the long run. Second, our empirical results confirm that there is a cointegrating relationship between interest rates and exchange rates for three sample countries (Brazil, India, and Turkey). However, unlike theoretical expectations, the sample countries' data do not confirm the existence of such a relationship for the remaining two sample countries (Indonesia and South Africa). Finally, the data affirm that there exists a long-run unidirectional Granger-causality between exchange rates and inflation running from the former to the latter.

Based on the empirical findings of the study, we can safely make the following arguments. The first argument is related to the Fisher hypothesis. The validity of the ex-post hypothesis allows us to make the following generalization: In the sample countries, in the long run, monetary policy actions do not influence real interest rates. In other words, monetary policy actions conducted by their monetary authorities of the sample countries do not create an effect on real interest rates. Rather, in the countries examined, real interest rates are determined by economic agents' decisions on consumption, saving, and investment and their reactions to keep purchasing power parity. The second argument is about the interest rates-exchange rates relationship. Interest rate policy does not guarantee exchange rate stability for the whole sample countries. For just three out of five countries (Brazil, India and Turkey), interest rate policy makes sense for stabilizing exchange rates. As a macroeconomic policy prescription, this empirical result suggests that market actors in these three countries can utilize interest rates in predicting movements in exchange rates. Having obtained such an empirical result may be explained especially on the ground of the following two things: First, high interest rate differentials (between domestic and foreign interest rates) in Brazil, India, and Turkey in relation to the remaining two sample countries (Indonesia and South Africa) make these countries more attractive to foreign capital inflows, ceteris paribus, resulting from an appreciation of the local currency or vice versa; and second, two sample countries, Indonesia and South Africa, have relatively lower private sector debt denominated in foreign currency compared to Brazil, India, and Turkey. A possible volatility in exchange rates emerged in countries with high private sector debt denominated in foreign currency affects treasury T-bonds' prices and, by implication, the interest rate on Tbonds.

Our last argument is on the relationship between exchange rates and inflation. Without exception, in all the sample countries, over the long run, persistent increases in the value of foreign currencies against the local currency produce an inflationary effect on domestic prices through import channel. This occurs via the pass-through effect from exchange rates to domestic inflation. Since these countries are highly import-dependent countries, a depreciation of their local currency pushes the price of imported goods up, and then price increases in imported goods mirror to domestic prices. 


\section{References}

Ahmad, S. (2010), “The Long-run Fisher Effect in Developing Economies", Studies in Economics and Finance, Vol: 27(4), pp. 268-275.

Arslaner, F., Karaman, D., Arslaner, N. and Kal, S.H. (2014), The Relationship between Inflation Targeting and Exchange Rate Pass-through in Turkey with a Model Averaging Approach, Central Bank of the Republic of Turkey Working Paper, No: 14/16, pp. 1-54.

Banerjee, A., Dolado, J. J. and Mestre, R. (1998), "Error-Correction Mechanism Tests for Cointegration in a Single-Equation Framework", Journal of Time Series Analysis, Vol: 19(3), pp. 267-283.

Barro, R. J. and Gordon, D. B. (1983), "A Positive Theory of Monetary Policy in Natural Rate Model", Journal of Political Economy, Vol: 91(4), pp. 589-610.

Barsky, R. B. (1987), “The Fisher Hypothesis and the Forecastability and Persistence of Inflation”, Journal of Monetary Economics, Vol: 19(1), pp. 3-24.

Berument, H. and Jelassi, M. M. (2002), “The Fisher Hypothesis: A Multi-Country Analysis”, Journal of Applied Economics, Vol: 34(13), pp. 1645-1655.

Boswijk, P. (1994), "Testing for an Unstable Root in Conditional and Structural Error Correction Models", Journal of Econometrics, Vol: 63(1), pp. 37-60.

Caporale, G. M. and Gil-Alana, L. (2017), Testing the Fisher Hypothesis in the G-7 Countries Using I(d) Techniques, DIW Berlin German Institute for Economic Research Discussion Papers, No: 1667, pp. $1-18$.

Carneiro F. G., Divino, J. A. C. A, and Rocha C. H. (2002), "Revisiting the Fisher Hypothesis for the Cases of Argentina, Brazil and Mexico", Applied Economics, Vol: 9(2), pp. 95-98.

Caselli, F. G. and Roitman, A. (2016), Non-Linear Exchange Rate Pass-Through in Emerging Markets, IMF Working Paper, Vol: 16(1), pp. 1-36.

Ca'Zorzi, M., Hahn, E., and Sánchez, M. (2007), Exchange Rate Pass-Through in Emerging Markets, ECB Working Paper, No: 739, pp. 1-31.

Chang, T. and Xu, Y.Y. (2012), Rational Bubbles in G-7 Countries: An Empirical Note Based on the ADL Test for Threshold Cointegration, in Asian Finance Association (Asian) and Taiwan Finance Association (TFA) Joint International Conference, pp. 6-9.

Chen, S. (2006), "Revisiting the Interest Rate-Exchange Rate Nexus: A Markov-Switching Approach", Journal of Development Economics, Vol: 79(1), pp. 208-224.

Choudhri, E. U. and Hakura, D. S. (2006), "Exchange Rate Pass-Through to Domestic Prices: Does the Inflationary Environment Matter?", Journal of International Money and Finance, Vol: 25(4), pp. 614-639.

Clarida, R. H. and Waldman, D. (2008), Is Bad News about Inflation Good News for the Exchange Rate? and, If So, Can That Tell Us Anything about the Conduct of Monetary Policy?, in John Campbell (Ed.), Asset Prices and Monetary Policy, Chicago: University of Chicago Press, pp. 371-396.

Cooray, A. (2002), The Fisher Effect: A Review of the Literature, Economics Research Papers, Macquarie University, Department of Economics, No: 0206, pp. 1-25. 
Coppock, L. and Poitras, M. (2000), "Evaluating the Fisher Effect in the Long-Term Cross-Country Averages", International Review of Economics and Finance, Vol: 9(2), pp. 181-192.

Crowder, W. J. and Hoffman, D. L. (1996), “The Long-run Relationship between Nominal Interest Rates and Inflation: The Fisher Equation Revisited", Journal of Money, Credit and Banking, Vol: 28(1), pp. 102-118.

Dash, P. (2004), The Relationship between Interest Rate and Exchange Rate in India, Sixth Annual Conference on Money and Finance in the Indian Economy, http://oii.igidr.ac.in:8080/jspui/bitstream/2275/214/1/dash_1_.pdf.

Devereux, M. B. and Yetman J. (2002), "Menu Costs and the Long Run Output-Inflation Trade-off”, Economics Letters, Vol: 76(1), pp. 95-100.

Dornbusch, R. (1976), "Expectations and Exchange Rate Dynamics", The Journal of Political Economy, Vol: 84(6), pp. 1162-1163.

Dornbusch, R. (2001), "Fewer Monies, Better Monies”, The American Economic Review, Vol: 91(2), pp. $238-242$.

Engle, R. F. and Granger, C. W. J. (1987), "Cointegration and Error Correction: Representation Estimation and Testing", Econometrica, Vol: 55(2), pp. 251-276.

Engsted, T. (1995), "Does the Long-Term Interest Rate Predict Future Inflation? A Multi-Country Analysis", The Review of Economics and Statistics, Vol: 77(1), pp. 42-54.

Fama, E. F. (1975), "Short-Term Interest Rates As Predictors of Inflation", The American Economic Review, Vol: 65(3), pp. 269-282.

Feldstein, M. S. (1986), “The Budget Deficit and the Dollar”, NBER Macroeconomics Annual, Vol: 1, pp. 355-392.

Fisher, I. (1961 [1930]), The Theory of Interest, New York: Macmillan.

Frankel, A. J. (1979), "On the Mark: A Theory of Floating Exchange Rates Based on Real Interest Differentials", The American Economic Review, Vol: 69(4), pp. 610-622.

Furman, J. and Stiglitz, J. (1998), "Economic Crises: Evidence and Insights from East Asia", Brooking Papers on Economic Activity, Vol: 1998(2), pp. 1-135.

Ghazali, N. A. and Ramlee, S. (2003), "A Long Memory Test of the Long-Run Fisher Effect in the G7 Countries”, Applied Financial Economics, Vol: 13(10), pp. 763-769.

Ghosh, A. R., Gulde, A-M, Ostry, J. D. and Wolf, H. C. (1997), Does the Nominal Exchange Rate Regime Matter?, NBER Working Paper, No: 5874, pp. 1-35.

Giavazzi, F. and Giovannini, A. (1989), Limiting Exchange Rate Flexibility, Cambridge, Mass.: MIT Press.

Goldfajn, I. and Baig, T. (2002), "Monetary Policy in the Aftermath of Currency Crises: The Case of Asia", Review of International Economics, Vol: 10(1), pp. 92-112. 
Güriş, B. and Yaşgül, Y. S. (2015), "Does the Fisher Hypothesis Hold for the G7 Countries? Evidence from ADL Threshold Cointegration Test", Quality \& Quantity, Vol: 49(6), pp. 2549-2557.

Hakkio, C. S. (1986), "Interest Rates and Exchange Rates-What is the Relationship?", Economic Review, Federal Reserve Bank of Kansas City, Vol: 71(9), pp. 33-43.

Harris, R. I. (1995), Using Cointegration Analysis in Econometric Modelling, London: Prentice Hall.

Hernandez-Verme, P. (2004), "Inflation, Growth and Exchange Rate Regimes in Small Open Economies", Economic Theory, Vol: 24(4), pp. 839-856.

Johansen, S. (1988), "Statistical Analysis of Cointegration Vectors", Journal of Economic Dynamics and Control, Vol: 12(2-3), pp. 231-254.

Kara, H. and Öğünç, F. (2008), "Inflation Targeting and Exchange Rate Pass-Through: The Turkish Experience”, Emerging Markets Finance \& Trade, Vol: 44(6), pp. 52-66.

Kataranova, M. (2010), "The Relationship between the Exchange Rate and Inflation in Russia”, Problems of Economic Transition, Vol: 53(3), pp. 45-68.

Kim, D-H, Lin S-C, Hsieh J. and Suen, Y. B. (2018), “The Fisher Equation: A Nonlinear Panel Data Approach", Emerging Markets Finance and Trade, Vol: 54(1), pp. 162-180.

Koustas, Z. and Serletis, A. (1999), "On the Fisher Effect”, Journal of Monetary Economics, Vol: 44(1), pp. 105-130.

Köse, N., Emirmahmutoğlu, F. and Aksoy, S. (2012), "The Interest Rate and Inflation Relationship Under an Inflation Targeting Regime: The Case of Turkey", Journal of Asian Economics, Vol: 23(4), pp. 476-485.

Lai, K. S. (2008), "The Puzzling Unit Root in the Real Interest Rate and Its Inconsistency with Intertemporal Consumption Behavior", Journal of International Money and Finance, Vol: 27(1), pp. $140-155$.

Lanne, M. (2001), "Near Unit Root and the Relationship between Inflation and Interest Rates: A Reexamination of the Fisher Effect", Empirical Economies, Vol: 26(2), pp. 357-366.

Leigh, D. and Rossi, M. (2002), Exchange Rate Pass-through in Turkey, IMF Working Paper, No: 02-204, pp. 1-19.

Levy-Yevati, E. and Sturzeegger, F. (2001), Exchange Rate Regimes and Economic Performance, IMF Staff Papers, Vol: 47, pp. 62-98.

Li, J. and Lee, J. (2010), “ADL Tests for Threshold Cointegration”, Journal of Time Series Analysis, Vol: 31(4), pp. 241-254.

Lu, Y.C.R., Chang, T. and Lee, C.H. (2012), "Nonlinear Adjustment to Purchasing Power Parity in Transition Countries: The ADL Test for Threshold Cointegration", Applied Economics Letters, Vol: 19(7), pp. 629-633.

MacDonald, R. and Murphy, P. D. (1989), "Testing for the Long Run Relationship between Nominal Interest Rates and Inflation Using Cointegration Techniques", Applied Economics, Vol: 21(4), pp. 439-447. 
Mignon V. and Lardic, S. (2003), "Fractional Cointegration between Nominal Interest Rates and Inflation: A Re-Examination of the Fisher Relationship in the G7 Countries", Economics Bulletin, Vol: 3(14), pp. 1-10.

Mishkin, F. S. (1992), "Is the Fisher Effect for Real? A Reexamination of the Relationship between Inflation and Interest Rates", Journal of Monetary Economics, Vol: 30(2), pp. 195-215.

Nusair, S. (2009), "Non-Linear Co-Integration between Nominal Interest Rates and Inflation: An Examination of the Fisher Hypothesis for Asian Countries", Global Economic Review, Vol: 38 (2), pp. $143-159$.

Pan, G., Chang, T., Tang, D. P. and Lee, C. H. (2012), "Nonlinear Adjustment to Purchasing Power Parity in Latin American Countries: The ADL Test for Threshold Cointegration", Applied Economics Letters, Vol: 19(9), pp. 857-862.

Patnaik, I., and Pauly, P. (2001), "The Indian Foreign Exchange Market and the Equilibrium Real Exchange Rate of the Rupee", Global Business Review, Vol: 2(2), pp.195-212.

Payne, J. E. and Ewing, B. T. (1997), "Evidence from Lesser Developed Countries on the Fisher Hypothesis: A Cointegration Analysis", Applied Economics Letters, Vol: 4(11), pp. 683-687.

Rossana, R. J. and Seater, J. J. (1995), “Temporal Aggregation and Economic Time Series”, Journal of Business \& Economic Statistics, Vol: 13(4), pp. 441-451.

Sargent, T. J. (1973), "Interest Rates and Prices in the Long Run: A Study of the Gibson Paradox”, Journal of Money, Credit and Banking, Vol: 5(1), pp. 385-449.

Sargent, T. J. and Wallace, N. (1981), "Some Unpleasant Monetarist Arithmetic", Federal Reserve Bank of Minneapolis Quarterly Review, Vol: 9(1), pp.15-31.

Sun, Y. and Phillips, P. C. B. (2004), "Understanding the Fisher Equation", Journal of Applied Econometrics, Vol: 19(7), pp. 869-886.

Tornell, A. and Velasco, A. (1995), "Fiscal Discipline and the Choice of Exchange Rate Regime", European Economic Review, Vol: 39(3-4), pp. 759-770.

Tsong, C. C. and Hachicha, A. (2014), "Revisiting the Fisher Hypothesis for Several Selected Developing Economies: A Quantile Cointegration Approach", Economic Issues, Vol: 19(1), pp. 57-72.

Udayaseelan, T. and Jayasinghe, P. (2010), The Validity of Fisher Hypothesis: Evidence from Sri Lanka, The Proceedings of the Seventh International Conference on Business Management, University of Sri Jeyawardenapura, Sri Lanka.

Velasco, A. (1996), "Fixed Exchange Rates: Credibility, Flexibility and Multiplicity”, European Economic Review, Vol: 40(3-5), pp. 1023-1035.

Westerlund, J. (2007), "Panel Cointegration Tests of the Fisher Effect", Journal of Applied Econometrics, Vol: 23(2), pp. 193-233.

Wicksell, K. (1907), “The Influence of the Rate of Interest on Prices”, The Economic Journal, Vol: 17(66), pp. 213-220.

Wicksell, K. (1936[1898]), Interest and Prices a Study of the Causes Regulating the Value of Money, London: Macmillan and Co. 